\title{
When Does Service-Learning Work? Contact Theory and Service-Learning Courses in Higher Education
}

\author{
Jerusha Conner \\ Villanova University
}

\author{
Joseph Erickson \\ Augsburg College
}

\begin{abstract}
Service-learning experiences have the potential to improve participants'attitudes and values toward those whom they serve, but if the experience is poorly designed or poorly implemented, it runs the risk of reinforcing stereotypes and deficit perspectives of the intended beneficiaries of service. This study examines the extent to which Contact Theory predicts the efficacy of service-learning courses in promoting positive attitude change among participants. Contact Theory stipulates the conditions under which attitude change toward an "out-group" becomes possible. Comparing pre-test and post-test scores for 220 students enrolled in service-learning courses in two different institutions, we find that courses that reflect more tenets of Contact Theory are more effective than those less aligned with Contact Theory in reducing students' overall colorblindness and improving their awareness of blatant racial issues.
\end{abstract}

Many who practice service-learning have the goal of affecting participants' attitudes and values, and research suggests that service-learning has the potential to impact learners in ways other forms of teaching may not (Delve, Mintz, \& Stewart, 1990; Holsapple, 2012). Service-learning has been found to be associated with a host of positive outcomes, including greater sensitivity and empathy (Bernacki \& Jaeger, 2008; Wilson, 2001); increased commitments to social justice (Eppler, Ironsmith, Dingle, \& Erickson, 2011; Fenzel \& Dean, 2011; Simons, Blank, Fehr, Barnes, Georganas, \& Manapuram, 2012); improved cultural competence or multicultural skills (Einfeld \& Collins, 2008; Meaney, Bohler, Kopf, Hernandez, \& Scott, 2008); and stereotype reduction (Conner, 2010a; Meaney et al., 2008; Wright, Calabrese, \& Henry, 2009). However, previous research also cautions that when poorly implemented, service-learning may result in unanticipated outcomes, such as increased prejudice and bias on the part of learners toward the very groups intended to benefit from their service (Erickson \& O'Connor, 2000; Erickson \& Santmire, 2001; Hollis, 2004; Jones, 2002; Kendall, 1990; Sperling, 2007). Those attempting to implement servicelearning in their classrooms may actually do more harm than good if they engage students in servicelearning experiences that afford casual contact; that is, contact between groups that is short-term, superficial, and lacking deep mutual engagement (Erickson \& O'Connor, 2000; Erickson \& Santmier, 2001; Houshmand, Spanierman, Beer, Poteat, \& Lawson, 2014). According to Allport (1984), "Such evidence as we have clearly indicates that such contact does not dispel prejudice; it seems more likely to increase it" (p. 263).

Changing attitudes and beliefs involves substantial reflection on one's values as well as the acquisition of new knowledge and skills (Holsapple, 2012). Lasting attitude changes are very difficult to achieve, and even if the service experience is carefully designed and well implemented, change may not occur for participants. Although numerous studies have examined the effects of servicelearning experiences on participants and uncovered some of the design features that seem to promote desired outcomes, such as the amount of time participants are engaged in service and the number of structured opportunities for reflection, the field of service-learning could benefit from more rigorous, large-scale studies that investigate the conditions under which desirable attitude change among participants does transpire. This study responds to that need.

\section{Literature Review}

How Participation in Service-Learning Affects College Students

Two recent literature reviews have affirmed the host of positive outcomes associated with servicelearning experiences. In their meta-analysis of 62 studies in which service-learning participants were compared to control students, Celio, Durlak, and Dymnicki (2011) found significant gains for 
service-learning participants in five areas: attitudes toward self; attitudes toward learning; academic performance; civic engagement; and social skills. Holsapple (2012) examined 55 studies that explored students' reports of the effects of servicelearning courses, and found that 32 of the studies documented findings related to students' confrontation of stereotypes they held about the diverse populations with whom they worked. This stereotype reduction was typically facilitated by the development of positive relationships with the served populations. Another key theme - increased knowledge about the served population - was found in 28 of the studies. Students reported greater awareness of cultural backgrounds, marginalization, and differences among individuals of a specific population. Additionally, students who participated in service-learning reported an enhanced appreciation of cultural diversity upon completion of the course, particularly among participants who worked with international and immigrant populations and K-12 school students.

Service-learning courses have demonstrated positive effects on students' prejudices, understanding of social problems, and commitment to social change. These effects are strengthened when developed in the context of high-quality instructional methods and strong, supportive relationships with site-supervisors (Batchelder \& Root, 1994). Indeed, a study conducted by Chang, Anagnostopoulos, and Omae (2010) sought to examine the effects of service-learning site characteristics, such as the quality of supervision students received, the type of organizations with which they worked, and the type of academic instruction they received, along with the degree of rigor of the reflection in which they were expected to engage. The particular course under examination, a multicultural service-learning course, was designed to facilitate interdependent partnerships and collaboration as well as critical thinking about social injustices. The study focused on 18 sections of this course, which engaged 212 students in 22 different service sites. After one semester, Chang et al. found that students who reported receiving more support from their site supervisors also reported a greater awareness of their personal biases and a reduction in previously held stereotypes toward low-income youth of color. Similarly, students who participated in courses with instructors who facilitated intense discussions surrounding the students' service-learning experiences and issues related to social inequities reported an increased consciousness of their prejudices and previously held stereotypes, a greater comprehension of cultural diversity and systemic inequities, and a dedication to working with disadvantaged populations in the future. In addition, the results indicate that forging positive relationships between the university and service sites as well as between the participants in the service-learning course and the populations with whom they serve are integral components of effective service-learning pedagogy. In addition to these pedagogical factors, Chang et al. found that white students became more aware of their biases over the course of the semester than did students of color. While the results of this study are informative, a major limitation is that the data were only collected from students at one university. Further studies are needed to replicate these findings to determine whether the results may be generalized to other populations of students participating in service-learning courses.

Forming interdependent relationships between individuals participating in service and the individuals with whom they are engaging is widely understood as crucial to effective service-learning (see review by Murphy \& Rasch, 2008). Without the formation of interdependent relationships and guided reflection, service-learning experiences may strengthen perceptions of privilege and reinforce stereotypes, just as some programs that attempt to reduce the stigma of a particular group end up reinforcing it (Hinshaw \& Stier, 2008). Houshmand et al. (2014) illustrate the potential harmful effects of service-learning experiences in their study of a service-learning course in which students were expected to collaborate with community partners from East St. Louis, a nearby predominantly African-American community, with nearly half of the population living below the poverty line. While students did not receive any direct instruction related to cultural diversity or whiteness, some course readings addressed multiculturalism, and students participated in some activities to increase their awareness of the community's cultural background, such as taking tours of the city to learn more about its history. Students made three site visits, each lasting two days, and engaged in various activities during these site visits, including conducting site analyses, holding individual meetings with community members, attending community meetings, and participating in service activities within the community. Houshmand et al. found, that upon completing the course, students confirmed the negative misconceptions they held regarding East St. Louis and its community members, students' experience as the "minority" in East St. Louis caused them discomfort as they perceived their appearance brought them extra unsolicited attention, and students attributed community problems to the fault of the residents of East St. Louis.

As evidenced by Chang et al. (2010) and Housh- 
mand et al. (2014), certain factors may facilitate or hinder the success of service-learning in influencing positive attitude change among participants. To gain a deeper understanding of how students' attitudinal changes occur as well as their personal views on their experience working at their servicelearning sites, researchers have analyzed in-depth student reflective writing, journal entries, interview data, and focus group transcripts (e.g., Baldwin, Buchanan, \& Rudisill, 2007; Boyle-Baise \& Kilbaine, 2000; Endres \& Gould, 2009; d'Arlach, Sánchez, \& Feuer, 2009; Greene, 1998; Hollis, 2004; Nenga, 2011; Simons, Fehr, Hogerwerff, Blank, Georganas, \& Russell, 2011). Deely (2010) conducted a study to fill the gap in research on the effects of service-learning from the students' perspective. Analyses of the data revealed several themes indicating students' positive and negative development throughout the service-learning experience. Asked to identify salient contextual and learning environment features, students indicated that their critical thinking skills were enhanced through coursework, community service, dialogue with small groups, analysis of readings, and journal writing. Moreover, students reported that having small class sizes made open dialogues easier and more comfortable, which facilitated honest discussions regarding personal experiences.

\section{Limitations of Existing Research}

As noted by Holsapple (2012), though qualitative measures provide insight into students' experiences and beliefs regarding social justice, an overemphasis on reflective measures in servicelearning research makes it difficult to evaluate in a quantifiable, statistically rigorous way the effects of participation in service-learning for different students. Specifically, reliance on reflective writing strategies as the sole means of data collection may limit the validity of the findings, as such measures may influence the nature of participants' responses, leading the responders to be vulnerable to response bias or responses driven by emotion (Hobbs, 2007). Additionally, research that has assessed the degree of reflection in student journals across an array of disciplines in higher education has found minimal, if any, consistency across methodological strategies for evaluating students' reflective writing (Dyment \& O'Connell, 2011).

Similarly, research conducted by instructors of service-learning courses may lead students to respond in a particular way. Students who completed reflective writing prompts as part of a course assignment (e.g., Endres \& Gould, 2009) may respond differently than if they had be given an anonymous survey that was not viewed as a course requirement (e.g., d'Arlach et al., 2009). While qualitative measures provide researchers with meaningful insight into students' experiences in service-learning, sense-making, and views of social injustices before and after their participation in the course, supplemental quantitative measures, administered by researchers not associated with the course, may serve to limit response bias and enhance validity. Indeed, a hybrid or mixed methods approach may offer the most promising research design, as exclusively quantitative studies run the risk of overlooking or over-simplifying the complex ways in which participants make meaning from their experiences (Snow \& Reeb, 2013).

In addition to the methodological limitations described above, studies of service-learning have been critiqued for their lack of theoretical frameworks to guide the research (Whitley, 2014). Without a guiding theory, it may be difficult to understand the exact mechanisms that contribute to or hinder the social and academic effects of service-learning. Indeed, a strong theoretical framework has been identified as "the most critical part of the research plan" (Ennis, 1999, p. 132) as it provides boundaries and guidelines to help develop the methods and interpret the results of the study. Without a conceptual focus, it may be difficult for researchers to pinpoint which components of the service-learning experience were most impactful for students (Moely, McFarland, Miron, Mercer, \& Ilustre, 2002).

This study responds to the call for servicelearning research that demonstrates empirical and methodological rigor and builds from a strong theoretical base in its investigation of the conditions under which service-learning courses facilitate authentic and desirable attitude change among participants. For more than 60 years, Gordon Allport's (1954) Contact Theory (CT) has been used by social psychologists to inform the design of strategies aimed at changing attitudes through human contact as well as evaluate the effectiveness of these strategies; however, few studies of service-learning have drawn on CT (for exceptions, see Conner 2010a; Murphy \& Rasch, 2008). Using CT to frame an analysis of the effects of service-learning courses at two institutions of higher education, this investigation examines to what extent service-learning courses promote changes in learners' attitudes and which design features of the service-learning experience are most associated with such changes.

\section{Theoretical Framework}

Contact Theory, also called the contact hypothesis, was introduced and developed by social psy- 
chologists to understand and evaluate the various conditions under which face-to-face contact would promote greater personal and social understanding between members of different groups (Allport, 1954; Amir, 1969; Cook, 1985). At its core, CT traces the minimum necessary conditions through which favorable experiences with individual members of an out-group may be transmitted or generalized to one's group-related attitudes (Pettigrew, 1988; Rothbart, 1996). The five main conditions of CT as outlined by Allport (1954) in his classic book, The Nature of Prejudice, include equal status contact; pursuit of common goals; intergroup cooperation; support of authorities, custom, or law; and sustained, long-term contact.

Since Allport first introduced his theory, researchers have extended and elaborated upon this original formulation. This new research has highlighted two additional factors that play an important role in facilitating attitude change for participants. These factors include instructional designs that attend to participants' affect, particularly students' anxiety about entering an unfamiliar environment and working with individuals with whom they lack previous experience (Pettigrew \& Tropp, 2000; 2005), and designs that ask participants to reflect on their identity and values (Celio, Durlak, \& Dymnicki, 2011; Fenzel \& Dean, 2011; Gaertner \& Dovidio, 2000; Kenworthy, Turner, Hewstone, \& Voci, 2005; Simons et al., 2011). Research using CT suggests that these seven features of the learning environment represent the minimum conditions under which attitude change becomes possible. Although a meta-analysis (Pettigrew \& Tropp, 2006) across 713 independent samples raises some question about the necessity of these conditions, it does find "those samples that experienced carefully structured contact situations designed to meet Allport's optimal conditions achieved a markedly higher mean effect size than did other samples" in terms of prejudice reduction (p. 766).

In addition to prejudice reduction, CT has been profitably applied in research on stigma reduction. Anti-stigma programs involving direct contact between the general public and individuals with mental illnesses have been found to produce lasting changes in both behaviors and attitudes when the conditions of CT are met (Corrigan \& O'Shaughnessy, 2007). Interventions that comport with the conditions of CT also have been found to reduce stigma and myths about homelessness and promote positive attitudes and greater empathy toward people experiencing homelessness (Snow \& Reeb, 2013). Although CT has been effectively utilized in the study of anti-stigma programs, very limited work considers how CT might be applied to the context of service-learning.

To illustrate how CT might be used to inform the design of a service-learning course, we offer two hypothetical examples of courses that show different degrees of alignment with the tenets of Contact Theory. For the sake of the examples, we presume that both courses are offered at the same institution, and that this institution demonstrates strong support for service-learning, thereby meeting Allport's condition of support by authorities or institutional support.

"Understanding Poverty in America" is a large, lecture-based course in which students sign up to volunteer for one five-hour shift at a soup kitchen. The instructor does not provide an introduction or orientation to the soup kitchen for the students; instead, she gives them a handout with instructions about where to go, what to wear, and how to help the staff. In addition, students are expected to participate in a class "Day of Service" by volunteering to help with administrative tasks at a local homeless shelter or a welfare agency. The students are asked to draw on these experiences in their final exam; however, class time is devoted to lecture, and there is no opportunity during the semester to discuss or write about these experiences in greater depth. This course does not satisfy any of the following conditions of CT: equal status contact; pursuit of common goals; inter-group cooperation; long-term or sustained contact; or efforts to address participants' affective states. The course meets CT's condition of opportunities for personal reflection at a very low level.

"Urban Youth and Their Institutions" is a small, discussion-based course in which students spend two hours each week over the course of a semester at an under-resourced public high school where the college and high school students partner to develop design proposals for the vacant lot across the street from the school. As they are members of the community, the high school students possess local knowledge useful to completing this assignment, and the instructor is careful to draw attention to their expertise. Prior to their first meeting with the high school students, the college students are given an orientation by the course instructor and the high school principal who take them on a tour of the high school and spend time answering their questions. The high school students also meet with the university course instructor and the principal ahead of time to learn about the project and to have their questions answered. The service-learning course requires the college students to respond each week to prompts that engage them in personal reflection that synthesize the course readings and their service experiences, and the instructor sets aside class 
time for the students to discuss and make meaning about their experiences at the high school. In its design, this course satisfies the following conditions of CT: equal status contact; pursuit of common goals; inter-group cooperation; long-term or sustained contact; opportunities for personal reflection; and efforts to address participants' affective states. These two hypothetical examples of college courses illustrate how service-learning courses may demonstrate either high or low alignment with basic CT tenets.

\section{Research Questions and Hypotheses}

Based on extant research, we developed linked hypotheses for each of our three research questions. First, we asked if students enrolled in servicelearning courses demonstrate significant change in their attitudes toward racial minority groups, specifically with regard to colorblindness? Colorblindness is a viewpoint that holds that race and racial categories are no longer salient, and therefore these categories should be ignored and everyone should be seen as an individual (Richeson \& Nussbaum, 2004). We expected to see a statistically significant decline in overall colorblindness across the sample of students enrolled in service-learning courses; however, we also expected that the extent of change would vary across courses, with some courses showing strong mean levels of change and some showing no or little mean change. Second, we asked to what extent individual student characteristics might explain their degree of change in colorblindness. Here, we expected that students of color would experience less change than white students. We did not expect to see differences based on any other individual characteristics, such as class year or gender. Third, we asked to what extent a course's alignment with CT predicts students' degree of change in colorblindness. We hypothesize that the more a course is aligned with Contact Theory, the greater the change in colorblindness students would demonstrate, becoming less colorblind and more aware. We expected that each tenet of Contact Theory would be associated with positive attitude change, with no one tenet exerting a stronger or weaker influence than any other.

\section{Method}

\section{Research Design}

This study is designed to investigate the utility of $\mathrm{CT}$ in predicting attitude change among servicelearning participants. The study uses a pre- and post-test design. Other data sources included an instructor assessment of the course and course artifacts, such as syllabi and handouts, which were used to evaluate each course's alignment with CT, as explained below.

\section{Participants}

Participants included instructors and students in all service-learning courses $(N=13)$ offered during the spring semester at two mid-sized, private institutions of higher education, one located on the east coast $(n=7)$ and one in the midwest $(n=6)$. In one of the institutions, many of the students involved in service-learning courses also lived in a sophomore service-learning community, which required participation in at least one service-learning course a semester and involvement in a weekly reflective discussion group comprised of students across different courses and facilitated by a trained staff member. The 13 service-learning courses involved in this study spanned a range of disciplines from the humanities to social sciences, including Theology, Ethics, Sociology, Education, and Political Science. Class sizes ranged from nine students to 32 students. The service arrangement in each course also varied, with some instructors requiring students to serve together at the same site and other instructors offering students a range of pre-approved sites at which students could complete service hours. These sites included public schools and community centers, where college students mentor and tutor younger students; prisons and adult literacy centers, where college students work with adults to develop their reading and writing skills; and homeless shelters, where students prepared and served meals to temporary residents.

Of the 243 students in all 13 courses, a total of 220 students completed both surveys, for a $91 \%$ response rate. Fifty-five percent of the sample attended the east coast university and $45 \%$ attended the midwest college. Eighty-one percent of the sample reported that they were engaged in service-learning for their course. Students enrolled in the courses who were exempted by their instructors from fulfilling the service-learning requirements were included in the study, and this gave us a chance to examine whether or not their results differed from those engaged in service. The demographic makeup of the participants was as follows: $34 \%$ were males, $66 \%$ were females; $74 \%$ identified as white, $7 \%$ as Black or African-American, $11 \%$ as Asian or Pacific Islander, $6 \%$ as Latino/a or Hispanic, and $2 \%$ as mixed ethnicity or other; and $50 \%$ were sophomores, $38 \%$ were seniors, $4 \%$ were juniors, and $8 \%$ were Master's students; the sample did not include any first-year students. 


\section{Procedure}

After securing IRB approval for the study at both institutions, a two-pronged recruitment process was used to engage participants. First, the directors of service-learning at each university contacted instructors who used service-learning in their courses and invited them to participate in the study. The invitation letter and consent forms explained that the study would examine students' attitude change over the course of the semester. It otherwise ensured that the instructors were blind as to the focus of the study. Participation entailed completing a short survey about their course and agreeing to allow a researcher to come into their class to explain the study, distribute consent forms, and administer a baseline and follow-up survey. The baseline survey was administered during the first or second week of each course. Rather than putting their names on the surveys, students were instructed in the process of inventing a unique identifying number. The researcher returned during the last week of each course to administer and collect the post-surveys. Both the researcher and the survey instructions encouraged students to be as open and honest as they could be, assuring them that "there are no right or wrong answers." Because the course instructors did not see the student survey, they were not influenced by its content in how they taught the course. And because the instructors did not see the students' responses, and because the students' names did not appear on the surveys, any pressure students might have felt to respond in socially desirable ways was mitigated.

\section{Measures}

In addition to demographic questions, the survey included the Color-Blind Racial Attitudes Scale (CoBRAS), which measures social attitudes toward racial and ethnic minorities (Neville, Lilly, Duran, Lee, \& Browne, 2000). CoBRAS has been used extensively in studies of higher education (e.g., Lewis, Neville, \& Spanierman, 2012; Worthington, Navarro, Loewy, \& Hart, 2008), and validation studies have found that higher scores on each of the three CoBRAS factors and the total score are related to greater racial and gender intolerance, racial prejudice, and belief that the world is just (Neville, Lilly, Duran, Lee, \& Browne, 2000). The scale consists of 20 items loading onto three factors: Unawareness of Racial Privilege, Unawareness of Institutional Discrimination, and Unawareness of Blatant Racial Issues. Representative items that load onto the Unawareness of Racial Privilege factor read: "Everyone who works hard, no matter what race they are, has an equal chance to become rich;" and "Race plays a major role in the type of social services (such as type of health care or day care) that people receive in the U.S." The latter item is reverse-coded. Sample items for the Unawareness of Institutional Discrimination factor are: "It is important that people begin to think of themselves as American and not African American, Mexican American or Italian American" and "White people in the U.S. are discriminated against because of the color of their skin." Sample items for the Unawareness of Blatant Racial Issues are: "Racism may have been a problem in the past, but it is not an important problem today" and "Talking about racial issues causes unnecessary tension." Each factor also includes more than one reverse-scored item. Reliability analyses for the current study yielded Cronbach's alphas on the pre- and post-surveys ranging from .71 to .85 . Change in these three factors and in overall colorblindness scores from pre- to post-surveys constitute the dependent variables of this study.

\section{Analytic Approach}

To assess the degree to which each course satisfied the seven tenets of Contact Theory, we relied on an instructor survey, course artifacts, and follow-up instructor interviews. Each course instructor completed a survey that contained several questions about the design of the course and its approach to service-learning. These questions mapped onto the CT tenets by asking about the extent to which the instructor experienced institutional support for the service; designed service experiences that were spread out and sustained over the course of the semester; attempted to reduce status disparities between the server and the served; designed the experience around shared goals for the server and the served; encouraged intergroup cooperation between the server and the served; attempted to address participants' anxiety and concerns about service; and attempted to rouse a sense of personal identity among students in the course. In addition, syllabi and relevant course handouts were coded by two researchers at each institution (the co-principal investigators and their trained graduate students) for the extent to which these artifacts reflected these seven tenets of CT. In coding these documents, we used a protocol (see Appendix A) to determine the extent to which each condition of CT each course met. We then compared instructor survey data with our ratings, and used decision rules and in some cases instructor interviews to reconcile any discrepancies. Following the collection of all survey data, we interviewed six of the course instructors as a means of member-checking. 
For each course, pre- and post-surveys were matched according to the unique identifying numbers students had created. Pre- or post-surveys without a match were dropped from the analysis. Other missing data were handled through a process of listwise deletion. Data were analyzed using inferential statistical tests, including paired t-tests for comparing pre- and post-scores; independent t-tests for comparing post-scores by groups, such as gender and service participation; two-way ANOVAs; and hierarchical linear regressions.

\section{Results}

To address our first research question, we compared the pre- and post-test scores of all students and found statistically significant declines in overall colorblindness, $t(202)=3.71, p<.000$, as well as on two of the three factors for all participants: unawareness of racial privilege, $t(202)=2.70, p<$ .01 , and unawareness of blatant racial issues, $t(202)$ $=2.98, p<.01$. In addition, as we expected, we found that mean change scores varied considerably across courses (See Table 1).

Before turning to our second research question about how differences in degree of change from pre-post were related to students' individual characteristics, we first examined whether there were any significant baseline differences in pre-test scores based on student characteristics. While there were no significant differences by year in school, white students were significantly more colorblind than students of color in the pre-test, posting significantly higher levels of unawareness on each factor and on overall colorblindness, $t(213)=-3.48, p$ $<.001$. White students showed greater unawareness of racial privilege, $t(135)=-1.96, p<.05$, unawareness of institutional discrimination, $t(213)=-4.58$, $p<.000$, and unawareness of blatant racial issues, $t(213)=-2.24, p<.05$ than their non-white counterparts at the baseline. Males were also significantly more colorblind than females at the baseline, on overall colorblindness, $t(213)=2.61, p<.01$, on unawareness of institutional discrimination, $t(213)$ $=2.61, p<.01$, and on unawareness of blatant racial issues, $t(213)=3.47, p<.001$. Finally, those students who did not plan to do service for the course were significantly more colorblind than their counterparts who did intend to do service at the baseline, on overall colorblindness, $t(212)=-1.95, p<$ .05 , on unawareness of institutional discrimination, $t(212)=-2.15, p<.05$, and on unawareness of racial privilege, $t(212)=-2.24, p<.05$.

We then considered differences in the degree of change pre-post by these same characteristics. We found no statistically significant differences based on students' year in school or race and ethnicity. Males showed significantly more change than females on unawareness of blatant racial issues, $t(201)=2.5, p<.01$ and on overall colorblindness, $t(201)=2.18, p<.05$. Two-way repeated measure ANOVA tests, using pre- and post-tests and comparing those engaged in service for the course to those exempt from service, showed a significant main effect for time (pre- to post-test) on colorblindness, $F(1,202)=7.836, p=.006, \eta^{2}=.038$ (See Table 2). Both those students who did service for the course and those exempt from service declined in overall colorblindness over the course of the semester; however, the interaction between service participation and time was not significant.

Turning to our third research question and the re-

Table 1

Trends in Mean Change Scores across Courses

\begin{tabular}{lccc}
\hline & $\begin{array}{c}\text { Number of courses with } \\
\text { negative change (students } \\
\text { become less aware/more } \\
\text { blind) Range }\end{array}$ & $\begin{array}{c}\text { Number of courses } \\
\text { with no change }\end{array}$ & $\begin{array}{c}\text { Number of courses with } \\
\text { positive change (students } \\
\text { become more aware/less } \\
\text { blind) Range }\end{array}$ \\
\hline Unawareness of Racial Privilege & 3 & 1 & 9 \\
& -.14 to -.26 & 0 & .06 to .58 \\
Unawareness of Blatant Racial & 3 & 0 & 10 \\
Issues & -.01 to -.17 & .10 to .35 \\
Unawareness of Institutional & 5 & 0 & 8 \\
Discrimination & -.02 to -.17 & 2 & .04 to .49 \\
Overall Colorblindness & -.02 to -.11 & 11 \\
\end{tabular}


Table 2

Mean Level of Colorblindness by Time and Service Participation

\begin{tabular}{lccc}
\hline & $\begin{array}{c}\text { Engaged in Service } \\
\text { for Course }\end{array}$ & Mean & S.D. \\
\hline Colorblindness Pre-test & Yes & 2.84 & .68 \\
& No & 3.09 & .80 \\
Colorblindness Post-test & Yes & 2.74 & .69 \\
& No & 3.00 & .87 \\
\hline
\end{tabular}

Table 3

Regression Results for Overall Colorblindness and Each Factor on Post-Test

\begin{tabular}{|c|c|c|c|c|}
\hline & $\begin{array}{l}\text { Colorblindness } \\
\text { Coefficient }\end{array}$ & $\begin{array}{c}\text { Un RP } \\
\text { Coefficient }\end{array}$ & $\begin{array}{c}\text { Un ID } \\
\text { Coefficient }\end{array}$ & $\begin{array}{c}\text { Un BRI } \\
\text { Coefficient }\end{array}$ \\
\hline Gender $(0=$ male $)$ & -.07 & -.02 & -.05 & -.12 \\
\hline Year & -.05 & .08 & -.03 & .07 \\
\hline Service $(0=$ yes $)$ & .05 & -.08 & $.18 *$ & .02 \\
\hline \multicolumn{5}{|l|}{ Service-Learning Community } \\
\hline$(0=$ yes $)$ & $.20 *$ & .14 & .11 & $.27 * *$ \\
\hline Race and Ethnicity $(0=$ non-white $)$ & .07 & .02 & .13 & .02 \\
\hline Pre-test & $.70 * * * *$ & $.77 * * * *$ & $.38 * * * *$ & $.48 * * * *$ \\
\hline Course Contact Theory & $-.17 *$ & -.10 & -.09 & $-.25 * *$ \\
\hline$F$ & $16.23 * * * *$ & $21.55^{* * * *}$ & $3.87 * * *$ & $6.03 * * * *$ \\
\hline Adjusted $R^{2}$ & .51 & .59 & .17 & .26 \\
\hline
\end{tabular}

Note. $* p<.1 ; * * p<.05$; *** $p<.01$; ****, $\mathrm{p}<.001$. Un RP indicates Unawareness of Racial Privilege; Un ID indicates Unawareness of Institutional Discrimination; Un BRI indicates Unawareness of Blatant Racial Issues.

gression analyses, we found that when we controlled for demographic factors and pre-test scores, courses with higher alignment with CT conditions did predict lower levels of overall colorblindness on the post-test, consistent with our hypothesis. In addition, we found higher alignment with CT conditions to be associated with lower levels of unawareness of blatant racial issues on post-tests (See Table 3). Not doing service in the course was associated with higher levels of unawareness of institutional discrimination on the post-test, and being part of a service-learning community was associated with lower levels of colorblindness and lower levels of unawareness of blatant racial issues on the post-test.

Finally, analyzing each tenet of CT separately and controlling for gender, students' racial minority status, and whether or not he/she participated in service, we found that certain tenets of CT appear to play more important roles in colorblindness reduction than others. Specifically, cooperation between students and those with whom they served and institutional support for the service each generates significant associations with the degree of change in students' CoBRAS results from pre to post-test. Whether or not the course encouraged cooperation between students and those with whom they served is significantly associated with change in unawareness of institutional discrimination, $B=.32 t(201)=$ $2.72, p<.01$ and change in overall colorblindness,
$B=.236 t(201)=1.99, p<.05$, even when all other CT tenets are included in the model (See Table 4). Furthermore, when added independently through a stepwise regression, cooperation explained a significant portion of the variance in change in institutional discrimination scores, $R 2=.05, F(10,191)$ $=1.97, p<.05$. A second CT tenet, the level of institutional support for the service activity, is significantly associated with change in unawareness of blatant racial issues, $B=.25 t(201)=1.71, p<.01$ and when added independently through a step-wise regression, institutional support explained a significant portion of the variance in change in blatant racial issues scores, $R 2=.05, F(10,191)=2.15, p$ $<.05$. For the three outcome variables mentioned above (unawareness of institutional discrimination, unawareness of blatant racial issues, and overall colorblindness), gender was also a significant predictor; being female was consistently associated with less pre-post change than being male.

\section{Discussion}

Our findings affirmed some of our study's hypotheses, while challenging others. First, as expected, we found that on average, students who were enrolled in service-learning courses, regardless of whether or not they were actually engaged in the service activity, demonstrated improved attitudes, 
When Does Service-Learning Work?

Table 4

Regression Results for Change in Colorblindness and Each Factor between Pre-Test and Post-Test

\begin{tabular}{|c|c|c|c|c|}
\hline & $\begin{array}{l}\text { Colorblindness } \\
\text { Change Score } \\
\text { Coefficient }\end{array}$ & $\begin{array}{c}\text { Un RP } \\
\text { Change Score } \\
\text { Coefficient }\end{array}$ & $\begin{array}{c}\text { Un ID } \\
\text { Change Score } \\
\text { Coefficient }\end{array}$ & $\begin{array}{c}\text { Un BRI } \\
\text { Change Score } \\
\text { Coefficient }\end{array}$ \\
\hline Gender $(0=$ male $)$ & $-.176 * *$ & -.014 & $-.15 * *$ & $-.191 * * *$ \\
\hline Race and Ethnicity $(0=$ non-white $)$ & .089 & .043 & .029 & .112 \\
\hline Service $(0=$ yes $)$ & .005 & .049 & -.051 & .003 \\
\hline Institutional Support & .095 & -.17 & .172 & $.250 *$ \\
\hline Spread Out & .163 & .064 & .286 & -.059 \\
\hline Reduce Status Disparity & -.084 & .106 & -.305 & .026 \\
\hline Common Goals & -.175 & -.157 & -.034 & -.131 \\
\hline Cooperative Work & $.236 * *$ & .116 & $.319 * * *$ & -.015 \\
\hline Concerns Addressed & -.286 & -.069 & -.418 & -.062 \\
\hline Reflection on Identity & .221 & .03 & .213 & .206 \\
\hline $\mathrm{F}$ & 1.55 & .81 & $1.97 * *$ & $2.15 * *$ \\
\hline Adjusted $\mathrm{R}^{2}$ & .027 & .009 & .046 & .054 \\
\hline
\end{tabular}

Note. $* p<.1 ; * p<.05 ; * * * p<.01 ; * * *, p<.001$. Un RP indicates Unawareness of Racial Privilege; Un ID indicates Unawareness of Institutional Discrimination; Un BRI indicates Unawareness of Blatant Racial Issues.

showing declines in colorblindness over the course of the semester. Nonetheless, as we predicted, some courses were more effective at promoting positive attitude change than others. Though limited to a small number of cases, certain courses indeed appeared to do more harm than good by impeding positive attitude change and reinforcing or increasing students' average colorblindness over the course of the semester.

With respect to our second set of hypotheses regarding individual differences, we were not surprised to find that students of color demonstrated significantly less colorblindness than white students at the outset of the study; however, we were surprised to find that white students did not experience more change over the course of the semester on our dependent variable than students of color. Also contrary to our expectations, we found significant results by gender. Male students came into the courses with higher levels of unawareness than their female classmates. They then experienced significantly greater change in their levels of unawareness over the course of the semester, such that by the end of the course, their scores were statistically indistinguishable from those of the females; in their end-of-term levels of awareness, males had caught up to the females. This result suggests that servicelearning can have a particularly profound effect on male students' attitudes, helping to make men more aware of institutional discrimination and blatant racial issues.

In terms of what might explain different courses' effectiveness facilitating attitude change, the results from this study show that courses that align with more CT tenets are more successful than courses that do not reflect as many of the guiding $\mathrm{CT}$ principles in promoting attitudinal change among stu- dents. This result was consistent with our hypothesis that greater alignment would be associated with greater positive change. However, where we expected all CT tenets to matter equally, the results of our study draw attention to two in particular as most strongly associated with attitude change: promoting cooperation between students and those with whom they serve and receiving or communicating institutional support for the service. These findings generate important implications for the design of service-learning experiences, and suggest concrete ways in which instructors can be aided in fostering attitude change for their students. Inter-group cooperation has long been considered a hallmark of effective service-learning. It is widely understood as an important component of reciprocal relationships, which are considered the gold-standard in servicelearning (Anderson \& Hill, 2001; Bailis, 2000; Conner, 2010b; Donahue, Bowyer \& Rosenberg, 2003; Jacoby, 2003). Comparatively less attention has been paid to the importance of institutional support in the service-learning literature. Nonetheless, institutional support has emerged as an important condition in effective anti-stigma programs (Hinshaw \& Stier, 2008). Our findings underscore the salience of institutional support. Higher levels of institutional support may signal to students that the work they are doing for the course is important and valued by others beyond the professor and the beneficiaries of service. Further research is needed to understand how these messages of institutional support might influence students and the nature of their interactions with the service recipients; it does, however, seem possible that higher levels of institutional support could establish a foundation of institutional relationships upon which stronger interpersonal relationships can then be built. 
Our finding about the importance of institutional support also aligns with our finding of the modest but significant association between being a member of a "service-learning community" and post-test colorblindness and unawareness of blatant racial issues scores. Even after controlling for pre-test scores, we found that those students who live with other students in a service-learning community are more likely to show lower levels of colorblindness and greater awareness of blatant racial issues on the post-test than their peers who do not live in such a community. A service-learning community may be one way an institution communicates its support for student engagement in service-learning. In addition, students in a service-learning community may have more informal opportunities to discuss, reflect on, and make sense of their service experiences and more occasions to hear from speakers who challenge them to think about issues of race and class than those who do not live in such a community. Of course, self-selection may also play a role in explaining the effects found among members of such a community.

Of the three factors that make up colorblindness, students' unawareness of their racial privilege presented a bit of a puzzle in our results. We found that students' levels of unawareness dropped significantly between pre- and post-surveys, meaning that they became more aware of their privilege over the course of the semester. This result is consistent with results found in other studies investigating the connection between service-learning and changes in students' awareness of white privilege (Fenzel \& Dean, 2011; Simons et al., 2012). However, where these previous studies could link this outcome to particular course features, such as personal identity reflection activities, we found no significant associations between this factor of CoBRAS and CT that could help explain declines in unawareness of racial privilege. Other contextual conditions and learning design features than those specified by CT may be responsible for these changes among our study participants, and future research is needed to resolve this inconsistency in the literature. Future research could also productively explore classroom-based orientation and content differences, which may have shaped our results, but which we did not consider in this study.

As with any study, the results should be viewed in light of the study's limitations. First, although we were careful to check the instructor's assessment of the course's alignment with CT against our own coding of course artifacts before ascribing a value for each tenet in our database, our ascriptions could have been strengthened had we either used raters who were blind to the purpose of the study and who achieved a strong, consistent inter-rater reliability score or had we engaged in further triangulation, including interviews with students and servicesite coordinators and observational data that could corroborate (or help us to refine) our ascriptions of value. Furthermore, for simplicity of analysis, we used dummy variables for each CT tenet; however, future research could use more graduated assessments of alignment. In addition, given the structure of our design, with students nested in courses, and courses nested in separate institutions of higher education, structural equation modeling might have been a useful analytic tool. Finally, it is worth noting that although we had a fairly robust sample in terms of its size, the sample was not very diverse, and our technique of grouping together students of color might have masked some finer-grained differences that would have emerged had we been able to compare students of different racial and ethnic backgrounds.

Despite these limitations, this study marks an advance in the field of service-learning, which has come under criticism for its lack of empirical and methodological rigor (Hironimus-Wendt \& LovellTroy, 1999; Sperling, 2007). We build on a small but growing body of research that applies quantitative methods to the study of service-learning outcomes for students (Astin \& Sax, 1998; Bernacki \& Jaeger, 2008; Borden, 2007; Bowman, Brandenberger, Mick, \& Smeddley, 2010; Eppler et al., 2011; Eyler \& Giles, 1999; Fenzel \& Dean, 2011; Hamilton \& Fenzel, 1988; Simons et al., 2012). In addition to using previously validated measures, such as CoBRAS (Neville et al., 2000) to address threats to internal validity, we designed the study to include student participants in multiple courses at two different institutions, thereby responding to concerns about external validity leveled at researchers who study students in only one course or at one institution of higher education (Sperling, 2007). Finally, by using CT as the theoretical basis for this study, we respond to the critique that much service-learning research has been conducted without strong theoretical frameworks.

Contact Theory has been studied for over half a century. It cannot be considered new; however, this research suggests that the application of the theory to the service-learning field may offer new insights into the question of when service-learning works to facilitate positive attitude change among student participants. It is, after all, not only servicelearning research, but also service-learning practice that has lacked a robust theoretical undergirding. Though Allport might have predicted the findings of this study sixty years ago, his words serve as a helpful reminder to those who design and imple- 
ment service-learning with the goal of effecting attitude change among their students:

Prejudice may be reduced by equal status contact between majority and minority groups in the pursuit of common goals. The effect is greatly enhanced if this contact is sanctioned by institutional supports, and provided it is of a sort that leads to the perception of common interests and common humanity between members of the two groups. (1954, p. 231)

\section{References}

Allport, G. (1954). The nature of prejudice. Cambridge, MA: Addison-Wesley.

Amir, Y. (1969). Contact hypothesis in ethnic relations. Psychological Bulletin, 71(5), 319-342.

Anderson, J. \& Hill, D. (2001) Principles of good practice for service-learning in preservice teacher education. In J.B. Anderson, K. J. Swick, \& Y. Joost (Eds.), Service-learning in teacher education: Enhancing the growth of new teachers, their students, and communities (pp. 69-84). Washington DC: American Association of Colleges of Teacher Education.

Astin, A. W., \& Sax, L. J. (1998). How undergraduates are affected by service participation. Journal of College Student Development, 39(3), 251-263.

Bailis, L. N. (2000). Taking service-learning to the next level: Emerging lessons form the national community development program. Springfield, VA: National Society for Experiential Education.

Baldwin, S. C., Buchanan, A. M., \& Rudisill, M. E. (2007). What teacher candidates learned about diversity, social justice, and themselves from service-learning experiences. Journal of Teacher Education, 58(4), 315-327. doi: 10.1177/0022487107305259

Batchelder, T. H., \& Root, S. (1994). Effects of an undergraduate program to integrate academic learning and service: Cognitive, prosocial cognitive, and identity outcomes. Journal of Adolescence, 17(4), 341-355. doi: 10.1006/jado.1994.1031

Bernacki, M.L., \& Jaeger, E. (2008). Exploring the impact of service-learning on moral development and moral orientation. Michigan Journal of Community Service Learning, 14(2), 5-15.

Borden, A. W. (2007). The impact of service-learning on ethnocentrism in an intercultural communication course. Journal of Experiential Education, 30(2), 171183. doi: 10.1177/105382590703000206

Bowman, N. A., Brandenberger, J. W., Mick, C. S., \& Smedley, C. T. (2010). Sustained immersion courses and student orientations to equality, justice, and social responsibility: The role of short-term service-learning. Michigan Journal of Community Service Learning, 17(1), 20-31

Boyle-Baise, M., \& Kilbaine, J. (2000). What really happens? A look inside service-learning for multicultural teacher education. Michigan Journal of Community Service Learning, 7(1), 54-64.

Celio, C. I., Durlak, J., \& Dymnicki, A. (2011). A metaanalysis of the impact of service learning on students. Journal of Experiential Education, 34(2), 164-181.

Chang, S., Anagnostopoulos, D., \& Omae, H. (2011). The multidimensionality of multicultural service learning: The variable effects of social identity, context and pedagogy on pre-service teachers' learning. Teaching and Teacher Education, 27(7), 1078-1089. doi: 10.1016/j. tate.2011.05.004

Conner, J. O. (2010a). Learning to unlearn: How a servicelearning project helped teacher candidates to reframe urban students. Teaching and Teacher Education, 26(5), 1170-1177. DOI: 10.1016/j.tate.2010.02.001

Conner, J. O. (2010b). Building the reciprocal relationship: How students in an affluent private university and a low-income public high school became partners in service and learning. Information for Action: A Journal for Research on Service-Learning for Children and Youth, 3(2), 1-23.

Cook, S. (1985). Experimenting on social issues: The case of social desegregation, American Psychologist, 40(4), 452-460.

Corrigan, P. W. \& O’Shaughnessy, J. R. (2007). Changing mental illness stigma as it exists in the real world. Australian psychologist, 42(2), 90-97.

d'Arlach, L., Sanchez, B., \& Feuer, R. (2009). Voices from the community: A case for reciprocity in servicelearning. Michigan Journal of Community Service Learning, 16(1), 5-16.

Deely, S. (2010). Service-learning: Thinking outside the box. Active learning in higher education, 11(1), 43-53. doi: 10.1177/1469787409355870

Delve, C., Mintz, S., \& Stewart, G. (1990). Community service as values education. San Francisco: JosseyBass.

Donahue, D., Bowyer, J., \& Rosenberg, D. (2003). Learning with and learning from: Reciprocity in service learning in teacher education. Equity and Excellence in Education, 36(1), 15-27.

Dyment, J. E., \& O'Connell, T. S. (2011). Assessing the quality of reflection in student journals: A review of the research. Teaching in Higher Education, 16(1), 8197. doi: 10.1080/13562517.2010.507308

Einfeld, A., \& Collins, D. (2008). The relationships between service-learning, social justice, multicultural competence, and civic engagement. Journal of College Student Development, 49(2), 95-109.

Endres, D., \& Gould, M. (2009). "I am also in the position to use my whiteness to help them out": The communication of whiteness in service learning. Western Journal of Communication, 73(4), 418-436. doi: 10.1080/10570310903279083

Ennis, C. D. (1999). A theoretical framework: The central piece of a research plan. Journal of Teaching in Physical Education, 18(2), 129-140.

Eppler, M.A., Ironsmith, M., Dingle, S.H., \& Errickson, M.A. (2011). Benefits of service-learning for freshmen college students and elementary school children. 
Journal of the Scholarship of Teaching and Learning, 11(4), 102-115.

Erickson, J., \& O'Connor, S. (2000). Service-learning's effect on prejudice: Does it reduce or promote it? In C. O'Grady (Ed.), Transforming education, transforming the world: The integration of service-learning and multicultural education into higher education. Mahwah, NJ: Lawrence Erlbaum Associates.

Erickson, J., \& Santmire, T. (2001). Psychological bases of effective service-learning. In J. Anderson, K. Swick, \& J. Yff (Eds.), Strengthening service and learning in teacher education. Washington, DC: American Association of Colleges for Teacher Education and the ERIC Clearinghouse for Teaching and Teacher Education.

Eyler, J., Giles, D., (1999). Where's the learning in service-learning? San Francisco: Jossey-Bass.

Fenzel, M.L \& Dean, R. J. (2011). Changes in students' social justice and racial attitudes in an undergraduate child psychology service-learning course. Journal of Research on Service-learning in Teacher Education, 1(2), 20-30.

Gaertner, S. L., \& Dovidio, J. F. (2000). Reducing intergroup bias: The Common Ingroup Identity Model. Philadelphia: The Psychology Press.

Greene, D. (1998). Student perceptions of aging and disability as influenced by service learning. Physical \& Occupational Therapy in Geriatrics, 15(3), 39-55.

Hamilton, S.F., \& Fenzel, L.M. (1988). The impact of volunteer experience on adolescent social development: Evidence of program effects. Journal of Adolescent Research, 3(1), 65-80.

Hironimus-Wendt, R. J., \& Lovell-Troy, L. (1999). Grounding service-learning in social theory. Teaching Sociology, 27(4), 360-372.

Hinshaw, S. \& Stier, A. (2008). Stigma as related to mental disorders. Annual Review of Clinical Psychology, 4, 367-393. doi: 10.1146/annurev.clinpsy.4.022007.141245

Hobbs, V. (2007). Faking it or hating it: Can reflective practice be forced? Reflective Practice, 8(3), 405-417. doi: 10.1080/14623940701425063

Hollis, S. (2004). Blaming me, blaming you: Assessing service learning and participants' tendency to blame the victim. Sociological Spectrum, 24(5), 575-600.

Holsapple, M. A. (2012). Service-learning and student diversity outcomes: Existing evidence and directions for future research. Michigan Journal of Community Service Learning, 18(2), 5-18.

Houshmand, S., Spanierman, L. B., Beer, A. M., Poteat, P. V., \& Lawson, L. J. (2014). The impact of a servicelearning design course on white students' racial attitudes. Journal of Higher Education Outreach and Engagement, 18(2), 19-48.

Jacoby, B. (2003). Building partnerships for servicelearning. San Francisco: Jossey-Bass.

Jones, S. (2002). The underside of service learning. About Campus, 7(4), 10-15.

Kendall, J. \& Associates (1990). Combining service and learning: A resource book for community and public service. Raleigh, NC: National Society for Internships and Experiential Education.

Kenworthy, J., Turner, R., Hewstone, M., \& Voci, A. (2005). Intergroup contact: When does it work, and why? In J. Dovidio, P. Glick, \& L. Rudman (Eds.). On the nature of prejudice: Fifty years after Allport (pp. 278-292). Malden, MA: Blackwell.

Lewis, J., Neville, H., \& Spanierman, L. (2012). Examining the influence of campus diversity experiences and color-blind racial ideology on students' social justice attitudes. Journal of Student Affairs, 49(2), 119-136.

Meaney, K. S., Bohler, H. R., Kopf, K., Hernandez, L., \& Scott, L. S. (2008). Service learning and pre-service educators' cultural competence for teaching: An exploratory study. Journal of Experiential Education, 31(2), 189-208.

Moely, B. E., McFarland, M., Miron, D., Mercer, S., \& Ilustre, V. (2002). Changes in college students' attitudes and intentions for civic involvement as a function of service-learning experiences. Michigan Journal of Community Service Learning, 9(1), 18-26.

Murphy, J. W., \& Rasch, D. (2008). Service-learning, contact theory, and building black communities. Negro Educational Review, 59(1/2), 63-78.

Nenga, S. K. (2011). Volunteering to give up privilege? How affluent youth volunteers respond to class privilege. Journal of Contemporary Ethnography, 40(3), 263-289. doi: 10.1177/0891241611400062

Neville, H. A., Lilly, R. L., Duran, G., Lee, R. M., \& Browne, L. (2000). Construction and initial validation of the Color-Blind Racial Attitudes Scale (CoBRAS). Journal of Counseling Psychology, 47(1), 59-70.

Pettigrew, T. (1988). The intergroup contact hypothesis reconsidered. In M. Hewstone \& R. Brown (Eds.), Contact and conflict in intergroup encounters (pp. 169-195). Oxford, UK: Basil Blackwell.

Pettigrew, T. \& Tropp, L. (2000). Does intergroup contact reduce prejudice? Recent meta-analytic findings. In S. Oskamp (Ed.), Reducing prejudice and discrimination (pp. 93-114) Mahwah, NJ: Lawrence Erlbaum Associates.

Pettigrew, T. \& Tropp, L. (2005). Allport's intergroup contact hypothesis: Its history and influence. In J. Dovidio, P. Glick, \& L. Rudman (Eds.), On the nature of prejudice: Fifty years after Allport (pp. 262-277). Malden, MA: Blackwell.

Pettigrew, T. \& Tropp, L. (2006). A meta-analytic test of intergroup contact theory. Journal of Personality and Social Psychology, 90(5), 751-783.

Richeson, J. \& Nussbaum, R. (2004) The impact of multiculturalism versus color-blindness on racial bias. Journal of Experimental Social Psychology, 40(3), 417-423.

Rothbart, M. (1996). Category-exemplar dynamics and stereotype change. International Journal of Intercultural Relations. 20(3/4), 305-321.

Simons, L., Blank, N., Fehr, L., Barnes, K., Georganas, D., \& Manapuram, G. (2012). Another look at the dissemination of the racial identity interaction mod- 
el in a cultural-based service-learning course. In J. A. Hatcher \& R. G. Bringle, (Eds.), Understanding service-learning and community engagement: Crossing boundaries through research (pp. 47-71) Charlotte, NC: Information Age.

Simons, L., Fehr, L., Hogerwerff, F., Blank, N., Georganas, D., \& Russell, B. (2011). The application of racial identity development in academic-based service learning. International Journal of Teaching and Learning in Higher Education, 23(1), 72-83.

Snow, N. \& Reeb, R. (2013). Social stigma and homelessness. Journal of Psychological Practice, 18, 104139.

Sperling, R. (2007). Service-learning as a method of teaching multiculturalism to white college students. Journal of Latinos and Education, 6(4), 309-322.

Whitley, M. (2014). A draft conceptual framework of relevant theories to inform future rigorous research on student service-learning outcomes. Michigan Journal of Community Service Learning, 20(2), 19-40.

Wiersma, W. (2000). Research methods in education $\left(7^{\text {th }}\right.$ ed.) Boston: Allyn \& Bacon.

Wilson, J.C. (2011). Service-learning and the development of empathy in U.S. college students. Education \& Training, 53(2/3), 207-217.

Worthington, R., Navarro, R., Loewy, M., \& Hart, J. (2008). Color-blind racial attitudes, social dominance orientation, racial-ethnic group membership and college students' perceptions of campus climate. Journal of Diversity in Higher Education, 1(1), 8-19.
Wright, A., Calabrese, N., \& Henry, J. (2009). How service and learning came together to promote "cura personalis". International Journal of Teaching and Learning in Higher Education, 20(2), 274-283

\section{Authors}

JERUSHA CONNER (jerusha.conner@villano va.edu) is an associate professor of Education at Villanova University. Her research focuses on student engagement, student voice, and youth activism and organizing for educational improvement. Recent publications include Student Voice in American Education Policy (2015, National Society for the Study of Education Yearbook) and Contemporary Youth Activism: Advancing Social Justice in the United States (2016, Praeger).

JOSEPH ERICKSON (Erickson@augsburg.edu) is a professor of Education at Augsburg College. His research addresses service-learning in teacher education and technology integration in schools. He recently published Transforming Teacher Education through Service-Learning (2013, Information Age Publishing) and presented "Educating in the digital age: Why service-learning is more important now than ever" at the 2015 Asia Pacific Regional Conference on Service-Learning.

Appendix A

Service-Learning Study - Investigator Rating Sheet

Unique Course Number:

Directions: After reading the course syllabus and course materials related to the service-learning activities within this course, rate the degree to which you find evidence that the course reflects the following characteristics.

1

Strongly

Disagree
23

4

5

5

6

Strongly

Agree

1. The institution with which they are partnering supports the goals for this course.

2. __ It is evident students are required to spread out their service hours across the entire academic term and/or are discouraged them from doing all of their hours in a short period of time.

3. ___ The service-learning activities are designed in such a way as to reduce status disparities between students and the service recipients with whom they work.

4. Students and the service recipients with whom they work will pursue common goals.

5. Students will work cooperatively with the people they serve.

6. Students' concerns about aspects of their service placement that might make them anxious are or will be addressed.

7. __ Students are asked to reflect on their own values and identity as part of the service project. 


\title{
First-Year Student Motivations for Service-Learning: An Application of the Volunteer Functions Inventory
}

\author{
Andrew J. Pearl \\ University of North Georgia
}

\author{
Robert K. Christensen \\ Brigham Young University
}

\begin{abstract}
This study extends a line of research focused on motivational factors that contribute to first-year students' reasons for engaging in service-learning. Among first-year students, altruistically-motivated students (Christensen, Stritch, Kellough, \& Brewer, 2015) and minority students (Pearl \& Christensen, 2016) were not only more knowledgeable of service-learning upon entering college but they were also more interested in enrolling in service-learning. The present study employs the Volunteer Functions Inventory (VFI) (Clary et al., 1998) to explore the extent to which student traits are correlated with various motivations to enroll in service-learning courses. We examine student responses to the VFI survey instrument using multiple analysis of variance (MANOVA). Our findings establish a foundation that better accounts for students' "inputs" in order to better understand various service-learning outcomes. We discuss the implications of our findings as they relate to higher education administrators and instructors in order to close the gap between service-learning interest and enrollment, and to provide students with service-learning experiences that satisfy their motivations and help them achieve their goals.
\end{abstract}

A majority of service-learning research has focused on outcomes with relatively less attention paid to students' traits and motivations as antecedents of service-learning. The present study extends a line of research focused specifically on motivational factors that contribute to new students' reasons for engaging in service-learning. Among first-year students, altruistically-motivated students (Christensen, Stritch, Kellough, \& Brewer, 2015) and minority students (Pearl \& Christensen, 2016) were not only more knowledgeable of servicelearning upon entering college, but they were also more interested in enrolling in service-learning. The present study continues this line of exploratory motivations-as-antecedents research by employing the Volunteer Functions Inventory (VFI, Clary et al., 1998) to begin to better understand the extent to which student traits are correlated with various motivations to participate in service-learning. The VFI is a statistically-validated and widely-used instrument originally designed to understand the motivations for general volunteering behavior and the dimensions of those motivations. Bringle, Phillips, and Hudson (2004) recommended the VFI as a potential tool to investigate service-learning students' motivations. We take up that invitation in this paper.

\section{"Inputs" that Support Service- Learning Outcomes}

Service-learning's many benefits have long been documented in the literature through empirical re- search, case studies, program evaluations, and anecdotal evidence. Eyler, Giles, Stenson, and Gray (2001) provide a detailed, annotated bibliography of student outcomes as they relate to students' personal, social, learning, and career development, as well as their relationships to their higher education institutions. In general, the literature summarized by Eyler and her colleagues indicate overall positive outcomes for students in these varied developmental areas. The degree to which students experience positive gains in these areas has been found to be connected to the learning goals identified by instructors, specifically how critical reflection activities are framed and utilized in the course (Einfeld \& Collins, 2008).

More recently, Clayton, Bringle, and Hatcher (2012) edited a volume intended to advance the research on service-learning outcomes by identifying and suggesting theoretical bases through which continued studies could be conducted. Contributors provided detail on theoretical perspectives as they relate to students' cognitive outcomes (Fitch, Steinke, \& Hudson, 2012), academic learning outcomes (Jameson, Clayton, \& Ash, 2012), civic learning (Battistoni, 2012), personal development outcomes (Brandenberger, 2012), and intercultural competence (Deardorff \& Edwards, 2012).

Along with more purposeful inclusion of theoretical frameworks, investigators have also sought to gain a more nuanced understanding of the causal paths that specify how service-learning might affect student outcomes. For example, empirical re- 
search has been conducted to investigate the impact of individual course characteristics on student outcomes (Matthews, Pearl, \& Wilder, 2014; Moely \& Ilustre, 2014). Other empirical evidence suggests that students from diverse backgrounds may experience service-learning courses and the associated outcomes differently (e.g., Chesler \& Vasques Scalera, 2000; Coles, 1999; Green, 2001; Mitchell \& Donahue, 2009).

While a majority of the literature has focused on the environments and outcomes of servicelearning participation, less attention has been given to the "input" part of the equation in Astin's (2012) Input-Environment-Output (I-E-O) model. We argue that factors such as students' traits and motivations are prime candidates to better articulate the "input" landscape. For example, race, gender, socio-economic status, motivation, and previous experiences with voluntary behavior (to name just a few) are too often considered control variables - if considered at all - rather than a central focus of research. We propose that a purposeful investigation of student inputs, including student traits and motivations, is necessary. What, for example, drives students to consider enrolling in service-learning courses? We then can begin to understand more about why particular outcomes occur.

Considering students' "inputs" is an important step because this information could help servicelearning instructors and administrators take a more targeted approach for the recruitment of students to participate in service-learning and community engagement. This, in turn, could create more opportunity for a broader audience to take advantage of service-learning's many potential benefits and provide more insight than simply observing student growth after some process that occurs in a nebulous "black box." Causality is a difficult standard to meet, and some believe that it may be impossible to do in a service-learning context $(\mathrm{Bu}-$ tin, 2006), but the more we understand about the inputs, including student traits and motivations, the better we will be able to connect educational processes to student outcomes. That is the purpose of this exploratory study: to explicitly investigate (a) student race and gender, (b) a variety of motivational dimensions, and (c) their relationships as potentially significant service-learning inputs. We offer brief reviews of literature relevant to these inputs and then describe our data, methods, and findings. We conclude with a discussion that outlines implications of our findings as well as directions for future research.

\section{Individual Traits and Volunteering: Race and Gender}

Scholars who study general volunteering (outside of the service-learning context) document that women and minorities give time and resources differently than men and Whites. For example, women may generally volunteer more than men (Einolf, 2011) but in different domains and rates (see Musik $\&$ Wilson, 2008). The findings concerning race and volunteering are somewhat similar in that Whites may generally donate (e.g., Van Slyke, Ashley, \& Johnson, 2007) or volunteer (e.g., Rotolo, Wilson, \& Hughes, 2010) more than minorities, but there is also evidence that context, solicitation, and incentive mechanisms matter differently to White volunteers compared to minority volunteers (see Laurence, 2009; Van Slyke et al.). Our read of this volunteering literature is that gender and race differences are nuanced and may be contingent upon motivations, resources, incentives, and solicitation.

Voluntary behavior is influenced by an integration of multiple forms of capital (Wilson \& $\mathrm{Mu}$ sick, 1997). Empirical research has demonstrated that individuals with greater levels of human and social capital are more likely to volunteer (Brown \& Lankford, 1992; Bryant, Jeon-Slaughter, Kang, \& Tax, 2003; Mesch, Rooney, Steinberg, \& Denton, 2006; Smith, 2002), and the inverse is also true - lesser levels of human and social capital have been given as reasons for not volunteering (Musick, Wilson, \& Bynum, 2000). Human capital theory would suggest that differences in volunteering and charitable giving between racial and ethnic groups is attributable to differing resources (Mesch et al.); nevertheless, empirical research has suggested that Black volunteers may be more likely to volunteer in general (Van Slyke \& Escholz, 2002).

Fewer studies have explored these patterns in service-learning, but some recent scholarship suggests that among freshmen students at a large public land-grant institution in the southeast, minority students were not only more knowledgeable about service-learning entering college, but they were also more interested in enrolling in servicelearning (Christensen et al., 2015). However, national trends suggest that there remains a significant gap in service-learning enrollment - the majority of students taking service-learning courses are White (Jacoby, 2015).

What then causes this disparity between knowledge of and interest in service-learning and actual service-learning enrollment? Butin (2006) warned against the dangers of service-learning becoming a pedagogy designed to provide an experience primarily for the "Whitest of the White" students, and 
stressed the importance of taking a critical examination of service-learning and purposefully working toward finding a way to make service-learning accessible to all students, not just those who fit the traditional (and outdated) mold of what it means to be a college student. As with the broader volunteer literature, a more nuanced understanding is warranted to better understand surface-level trends.

In a qualitative analysis of open-ended student responses, Pearl and Christensen (2016) found that minority students report that they may be interested in fulfilling different needs through participation in service-learning than White students. In particular, minority students indicate that they are more driven by the public service aspect of service-learning than its academic aspects, suggesting that the gaps in participation rates in service-learning courses may, at least in part, be due to the fact that minority students can fulfill these motivations through other voluntary activities. Further, the academic component of service-learning may, in fact, be perceived as a barrier to service-learning participation if the primary goal of the student is to provide service to the community. Pearl and Christensen (2016) emphasize the importance of initiating conversations related to the differing motivations of students, including how those may relate to gender or race, in order to provide experiences that meet their needs and goals.

\section{The Volunteer Functions Inventory}

Grounded in the classical theoretical foundations of functionalism (i.e., Katz, 1960; Smith, Bruner, \& White, 1956), Clary et al. (1998) developed the Volunteer Functions Inventory (VFI) based on the belief that people may choose to engage in the same voluntary activity for different reasons. Simply put, different individuals may be fulfilling different psychological functions by engaging in the same activity. Through a series of six investigations, Clary et al. tested the validity and reliability of six motivational dimensions or "functions" for volunteering: values, enhancement, understanding, protective, social, and career.

The values function allows individuals to publicly express their values and demonstrate that they have "altruistic and humanitarian concerns for others" (Clary et al., 1998, p. 1517). Through the understanding function, individuals have the opportunity to learn new knowledge, skills, and abilities, as well as have the chance to experience and exercise their existing knowledge, skills, and abilities. The social function relies on the individual's relationships with others, providing volunteers with the opportunity to socialize with their family and/or friends and improve those relationships, meet new friends, and be viewed favorably by others, especially the social groups with which they associate. The career function suggests that volunteers may engage in service to develop, enhance, or maintain their career-related skills in pursuit of their chosen profession. The protective function is one which individuals pursue to protect the ego; for example, volunteering to reduce one's guilt for being more fortunate than others or to work through personal problems. Finally, the enhancement function, which also deals with the individual's ego, seeks to build the ego through motivational processes centering on positive development.

Considering motivational differences by gender, female volunteers generally score higher on the VFI than male volunteers (Fletcher \& Major, 2004; Okun, Barr, \& Herzog, 1998), although in a sample of medical students, men and women demonstrated similar patterns of the relative importance of the six VFI functions (Fletcher \& Major). Einolf (2011) found that although women may be more interested in volunteering and more motivated to engage in prosocial behavior, the resource, skills/education, and social capital advantages of men in many ways offset participatory differences. The literature also contains several examples of VFI investigations among older adults (i.e., Brayley, Obst, White, Lewis, Warburton, \& Spencer, 2014; Okun $\&$ Schultz, 2003), but a specific focus on race (and to some degree gender) thus far has been understudied. Lai, Ren, Wu, and Hung (2013) found that among the six functions of the VFI there was only a significant difference in the enhancement function between actual and potential Chinese volunteers, leading the authors to suggest at least a marginal impact of national identity on voluntary behavior. This may indicate that other elements of identity such as race and gender - may also have an impact on voluntary behavior.

Utilizing the VFI, the motivation to volunteer has been associated with other prosocial behaviors - in this case, organ donation - among a sample of Black individuals (Terrell, Mosley, Terrell, \& Nickerson, 2004). Differing levels of motivation, based on VFI scores, have been shown to be associated with variations in frequency of volunteering (Allison, Okun, \& Dutridge, 2002), in particular with the values function. Satisfaction with volunteering experiences has been found to be positively correlated with fulfillment of five of the six VFI functions, the career function being the exception (Finkelstein, 2008). Finkelstein also found that strongly-held motives were more likely to be fulfilled through an individual's volunteering. Subsequent testing of the VFI instrument has explored the utility of five func- 
tions (excluding the career function) and even three functions (combining the enhancement and protective functions and excluding the career and understanding functions) (Brayley et al., 2014). The research of Brayley et al. further supported previous research that found that the values function was a much greater predictor of sustained voluntary behavior than the social function.

Stukas, Clary, and Snyder (1999) further considered the utility of the VFI, extending its application to service-learning in higher education, particularly the potential functional motivations for students, institutions, and the communities being served. And Bringle et al. (2004) further recommended the VFI as a valuable tool to investigate students' motivations as they relate to service-learning.

Citing Olney and Grande (1995), Stukas et al. (1999) discussed the values function, observing that students often do not have the experience to have fully developed values and attitudes toward social responsibility. Instead, Stukas et al. review the literature that suggests that service-learning can develop prosocial values, although these positive outcomes are largely mediated by the quality of the student's service.

Related to the understanding function, Stukas et al. (1999) review the many ways students understand more about the world, particularly their academic gains, as well as their understanding of themselves and the communities in which they live. The quality of student understanding is largely reliant on the relevance of the service experience to the academic course content, and is facilitated through critical reflection.

Considering the social function, Stukas et al. (1999) suggest that students may elect to enroll in service-learning because they believe that they are expected to do so by the social groups with which they associate, including their families, peers, community leaders, and their institutions. Further, Stukas et al. cite the research that suggests that the relationships between students and instructors may be positively impacted through service-learning.

Because students are often still in the process of determining their future vocations, Stukas et al. (1999) observe that the career function generally comes into play for students as they gauge their potential fit in a particular major or career path, provided that the service activity has a clear connection to the development of knowledge and/or skills needed for a future profession. Stukas and colleagues also make reference to research indicating that service-learning can help students develop intrinsic work values and understand the importance of their future careers and work lives.
Stukas et al. (1999) believe that the protective function is relevant to students engaging in servicelearning because students may enroll in servicelearning to protect themselves from other stresses, reduce feelings of isolation, or improve attendance and behavior. These researchers also cite multiple examples of how service-learning can help students feel more engaged in the college experience, including the potential to improve attendance and reduce disciplinary problems.

Stukas et al. (1999) propose that the enhancement function is relevant to students enrolled in service-learning because these experiences can develop responsibility and autonomy in students as they are given opportunities to make meaningful choices, thereby building their self-esteem and selfefficacy. These researchers acknowledge that personal and situational factors may moderate these self-enhancement outcomes.

Some previous research involving college students has suggested that appealing to individuals' motivations is more likely to lead to successful recruitment of students to get involved in civic engagement initiatives, although the protective and social functions may be the weakest appeals of the six VFI functions (Schatteman, 2014).

Building from the above theoretical and conceptual frameworks, this exploratory study seeks to add to the extant literature by addressing the following two research questions. First, are there significant motivational differences for servicelearning among male and female students? Our hypothesis is that, based on previous research utilizing the VFI among volunteers, female students will express greater levels of motivation to participate in service-learning. Second, are there significant motivational differences for service-learning among White students and minority students? Our hypothesis is that, based on previous research of voluntary behavior (Mesch et al., 2006; Van Slyke \& Escholz, 2002), minority students will express greater levels of motivation to participate in service-learning than White students.

\section{Method}

To explore service-learning inputs of student traits (gender/race) and motivations (volunteer functions), we employ a quantitative analytic method. We examine student responses to a survey adapted from the original Clary et al. (1998) VFI. The student self-reported data are then analyzed using multiple analysis of variance (MANOVA). All analyses were conducted with SPSS. 


\section{Survey Instrument and Sampling Strategy}

We employed a purposive sampling strategy to intentionally include first-year students from multiple semesters, partnering with the institution's Office of Institutional Diversity (OID), Center for Student Organizations (CSO), and two sections of American Government, an introductory political science course that fulfills a general education requirement (the course was not a service-learning course). We sent a cover letter template and links to a Qualtrics survey instrument to the individuals responsible for managing the distribution lists for the above groups; therefore, we do not have access to the full list of students who received the invitation to participate. Therefore, we are unable to report a reliable response rate. Students were incentivized to participate in the survey by entering them into a random drawing for a gift card, and the study was approved by the university's Institutional Review Board (IRB).

Minor modifications were made in the wording of the VFI survey instrument. For example, "servicelearning" replaced "volunteering" throughout. A question was included at the beginning of the survey asking if students were currently enrolled in or had previously taken service-learning at the institution, leading them to differently-worded versions of the survey. The original VFI instrument utilizes a seven-point Likert scale; however, based on previous research that found no reduction in scale reliability and validity, our instrument utilizes a five-point Likert scale (Manud, 2014), where $1=$ Strongly Disagree, 2 = Disagree, $3=$ Neither Agree nor Disagree, $4=$ Agree, and $5=$ Strongly Agree . We also asked students to indicate whether or not they would be more likely to enroll in a servicelearning course or a traditionally taught course. Demographic information was collected related to students' race, gender, age, and socioeconomic status. Finally, to verify that we were surveying freshmen we asked students to indicate the number of semesters they had completed as well as their voluntary and charitable activities outside of their coursework. To provide guidance for students who were not previously familiar with service-learning, we provided a simple, introductory definition (see the Appendix to view the wording for each of the VFI items, both for the students who were either currently enrolled in or had previously taken servicelearning courses as well as the students who had no previous experience with service-learning). The descriptive statistics for the student responses are also provided in Appendix A.

\section{Analytic Methods}

Data were analyzed using multiple analysis of variance (MANOVA), a statistical technique used to test for differences in means between two or more groups, examining multiple dependent variables (e.g., multiple functions/dimensions of service-learning motivations). Huberty and Petoskey (2000) identify multiple perspectives on the purpose for conducting a MANOVA, and indicate the preferred purpose is to better understand the effect of at least one independent (or grouping) variable on the outcome variables, a recommendation we follow in this study. In this study, we examined six outcome variables to correspond to the six functions of the VFI (protective, values, career, social, understanding, and enhancement). As a means of data reduction, composite variables were derived for each of the six functions of the VFI using factor analysis prior to analysis. Using Chronbach's $\alpha$, we analyzed the reliability of the six composite variables. As shown in Table 1, acceptable or good levels were met for each of the composite variables (Tavakol \& Dennick, 2011).

Two variables were selected as grouping variables: students' self-reported race and students self-reported gender. In our sample of 130 students, only a small number $(n=58)$ identified themselves in various racial minority groups; therefore, respondents were re-coded to be either White or Racial Minority. Those included in the Racial Minority group identified themselves in the survey as either Hispanic/Latino, American Indian/Alaska Native, Asian, Black/African-American, Hawaiian/Pacific Islander, and/or Multiracial. We fully acknowledge

Table 1

Internal Reliability

\begin{tabular}{lcc}
\hline VFI Function & Chronbach's $\alpha$ (previous SL) & Chronbach's $\alpha$ (no previous SL) \\
\hline Career & 0.766 & 0.801 \\
Social & 0.834 & 0.778 \\
Values & 0.883 & 0.832 \\
Enhancement & 0.822 & 0.826 \\
Protective & 0.790 & 0.780 \\
Understanding & 0.871 & 0.856 \\
\hline
\end{tabular}


that this is an overly reductive view of race; however, this was necessary for the purposes of our analyses given our sample size.

Through qualitative analysis, Pearl and Christensen (2016) found that minority students may be interested in fulfilling different needs by enrolling in service-learning than White students. Consequently, the first model we ran includes only race as a grouping variable, the second model includes gender as a single grouping variable, the third model includes both race and gender as grouping variables, and the final model adds the interaction of race and gender as a grouping variable.

\section{Results}

In the following section, we discuss the MANOVA findings. As a means of providing guidance for the interpretation of our findings, we will be presenting the results of the multivariate tests and the tests of between-subjects effects. First, the multivariate tests address whether or not the grouping variables (i.e., race, gender) included in each model have a statistically significant effect for all of the dependent variables (VFI functions), considered as a group. The statistics reported for the multivariate test include the Wilks' $\lambda$ value, the results of the $F$ test for significance, the relevant degrees of freedom, the $p$ value (significance), the partial $\eta^{2}$ (as an estimate of effect size), and the observed power. The tests of between-subjects effects shows the univariate ANOVA results for the grouping variables in the respective models on each of the outcome variables, considered individually. The statistics reported for the tests of between-subjects effects include the sum of squares (Type III), degrees of freedom, mean square, results of the $F$ test for significance, the $p$ value (significance), the partial $\eta^{2}$ (as an estimate of effect size), and the observed power.

Because our sample of students included those who were either currently enrolled in, or had previously enrolled in, service-learning courses, as well as those who had no prior experience with servicelearning, we ran a MANOVA model to test whether or not previous experience with service-learning was associated with differences in student responses to the VFI items in the survey. In our sample, 39 students indicated that they had previously taken a service-learning course and 91 did not. As shown in Table 2, there was no statistically significant difference that emerged in students' motivations based on whether or not the student had previously tak-

Table 2

MANOVA Findings: Prior Service-Learning Experience as the Grouping Variable

Multivariate Test

\begin{tabular}{lcccccc} 
& Wilks' $\lambda$ & $F$ & $d f$ & Sig. & Partial $\eta 2$ & Power \\
\hline $\begin{array}{l}\text { Prior ser- } \\
\text { vice-learning } \\
\text { experience }\end{array}$ & .976 & .508 & $(6,123)$ & .801 & .024 & .199 \\
\hline
\end{tabular}

Tests of Between-Subjects Effects

\begin{tabular}{|c|c|c|c|c|c|c|c|c|}
\hline & VFI Function & $\begin{array}{c}\text { Type III Sum } \\
\text { of Squares }\end{array}$ & $d f$ & Mean Square & $F$ & Sig. & Partial $\eta 2$ & $\begin{array}{c}\text { Observed } \\
\text { Power }\end{array}$ \\
\hline \multirow{6}{*}{$\begin{array}{l}\text { Prior ser- } \\
\text { vice-learning } \\
\text { experience }\end{array}$} & Protective function & .253 & 1 & .253 & .244 & .622 & .002 & .078 \\
\hline & Values function & .178 & 1 & .178 & .142 & .707 & .001 & .066 \\
\hline & Career function & .223 & 1 & .223 & .184 & 669 & .001 & .071 \\
\hline & Social function & .493 & 1 & .493 & .428 & .514 & .003 & .100 \\
\hline & Understanding function & .241 & 1 & .241 & .204 & .653 & .002 & .073 \\
\hline & Enhancement function & .361 & 1 & .361 & .324 & .570 & .003 & .087 \\
\hline \multirow[t]{6}{*}{ Error } & Protective function & 132.457 & 128 & 1.035 & & & & \\
\hline & Values function & 160.566 & 128 & 1.254 & & & & \\
\hline & Career function & 155.333 & 128 & 1.214 & & & & \\
\hline & Social function & 147.385 & 128 & 1.151 & & & & \\
\hline & Understanding function & 151.353 & 128 & 1.182 & & & & \\
\hline & Enhancement function & 142.528 & 128 & 1.113 & & & & \\
\hline \multirow[t]{6}{*}{ Total } & Protective function & 132.710 & 129 & & & & & \\
\hline & Values function & 160.743 & 129 & & & & & \\
\hline & Career function & 155.556 & 129 & & & & & \\
\hline & Social function & 147.878 & 129 & & & & & \\
\hline & Understanding function & 151.594 & 129 & & & & & \\
\hline & Enhancement function & 142.888 & 129 & & & & & \\
\hline
\end{tabular}


Table 3

Descriptive Statistics

\begin{tabular}{|c|c|c|c|c|c|}
\hline \multicolumn{2}{|l|}{ Grouping Variables } & & & \multirow[b]{8}{*}{ Std. Dev. } & \multirow[b]{8}{*}{$n$} \\
\hline Race & $\mathrm{n}$ & & & & \\
\hline White & 72 & & & & \\
\hline Minority & 58 & & & & \\
\hline \multicolumn{2}{|l|}{ Gender } & & & & \\
\hline Female & 104 & & & & \\
\hline Male & 26 & & & & \\
\hline VFI Functions & Race & Gender & Mean & & \\
\hline \multirow[t]{9}{*}{ Protective function } & \multirow[t]{3}{*}{ White } & Female & $-.1002(3.2264)$ & 1.03018 & 58 \\
\hline & & Male & $-.4205(2.9971)$ & .94573 & 14 \\
\hline & & Total & -.1625 (3.1789) & 1.01590 & 72 \\
\hline & \multirow[t]{3}{*}{ Minority } & Female & $.3241(3.4450)$ & 1.00163 & 46 \\
\hline & & Male & $-.2940(3.0750)$ & .76970 & 12 \\
\hline & & Total & $.1962(3.353)$ & .98498 & 58 \\
\hline & \multirow[t]{3}{*}{ Total } & Female & $.0875(3.3214)$ & 1.03464 & 104 \\
\hline & & Male & $-.3621(3.0348)$ & .85434 & 26 \\
\hline & & Total & $-.0024(3.2575)$ & 1.01428 & 130 \\
\hline \multirow[t]{9}{*}{ Values function } & \multirow[t]{3}{*}{ White } & Female & $-.0982(4.3031)$ & 1.09629 & 58 \\
\hline & & Male & $-.2633(4.2235)$ & 1.09966 & 14 \\
\hline & & Total & $-.1303(4.2866)$ & 1.09115 & 72 \\
\hline & \multirow[t]{3}{*}{ Minority } & Female & $.3205(4.4880)$ & .90902 & 46 \\
\hline & & Male & $-.9467(3.6313)$ & 1.43341 & 12 \\
\hline & & Total & $.0583(4.2803)$ & 1.14759 & 58 \\
\hline & \multirow[t]{3}{*}{ Total } & Female & $.0870(4.3835)$ & 1.03430 & 104 \\
\hline & & Male & $-.5787(3.9364)$ & 1.28590 & 26 \\
\hline & & Total & $-.0462(4.2838)$ & 1.11628 & 130 \\
\hline \multirow[t]{9}{*}{ Career function } & \multirow[t]{3}{*}{ White } & Female & $-.1255(3.8285)$ & 1.05014 & 58 \\
\hline & & Male & $-.4405(3.6824)$ & 1.01420 & 14 \\
\hline & & Total & $-.1867(3.7982)$ & 1.04376 & 72 \\
\hline & Minority & Female & $.4220(4.1560)$ & 1.00079 & 46 \\
\hline & & Male & $-.8420(3.3781)$ & 1.13039 & 12 \\
\hline & & Total & $.1605(3.9674)$ & 1.14196 & 58 \\
\hline & Total & Female & $.1167(3.9709)$ & 1.05949 & 104 \\
\hline & & Male & $-.6258(3.5348)$ & 1.06712 & 26 \\
\hline & & Total & $-.0318(3.8736)$ & 1.09812 & 130 \\
\hline Social function & White & Female & $-.0846(3.1138)$ & 1.05962 & 58 \\
\hline & & Male & $-.3879(3.1235)$ & 1.23936 & 14 \\
\hline & & Total & $-.1436(3.1159)$ & 1.09419 & 72 \\
\hline & Minority & Female & $.2506(3.3760)$ & 1.05495 & 46 \\
\hline & & Male & $-.1428(3.1219)$ & .86215 & 12 \\
\hline & & Total & $.1692(3.3144)$ & 1.02367 & 58 \\
\hline & Total & Female & $.0637(3.2278)$ & 1.06563 & 104 \\
\hline & & Male & $-.2748(3.1227)$ & 1.06832 & 26 \\
\hline & & Total & $-.0040(3.2044)$ & 1.07067 & 130 \\
\hline Understanding function & White & Female & $-.1442(4.1592)$ & 1.03927 & 58 \\
\hline & & Male & $-.3686(4.0235)$ & 1.01411 & 14 \\
\hline & & Total & $-.1879(4.1311)$ & 1.03122 & 72 \\
\hline & Minority & Female & $.3454(4.4120)$ & .95483 & 46 \\
\hline & & Male & $-.9136(3.7281)$ & 1.26453 & 12 \\
\hline & & Total & $.0849(4.2462)$ & 1.13711 & 58 \\
\hline & Total & Female & $.0723(4.2691)$ & 1.02749 & 104 \\
\hline & & Male & $-.6202(3.8803)$ & 1.14679 & 26 \\
\hline & & Total & $-.0662(4.1824)$ & 1.08404 & 130 \\
\hline Enhancement function & White & Female & $-.0886(3.7900)$ & 1.09431 & 58 \\
\hline & & Male & $-.5060(3.5735)$ & .90707 & 14 \\
\hline & & Total & $-.1698(3.7451)$ & 1.06757 & 72 \\
\hline & Minority & Female & $.2922(3.9700)$ & .97187 & 46 \\
\hline & & Male & $-.5293(3.5406)$ & .96784 & 12 \\
\hline & & Total & $.1222(3.8659)$ & 1.01937 & 58 \\
\hline & Total & Female & $.0798(3.8683)$ & 1.05427 & 104 \\
\hline & & Male & $-.5167(3.5576)$ & .91659 & 26 \\
\hline & & Total & $-.0395(3.7990)$ & 1.05245 & 130 \\
\hline
\end{tabular}

Note: The means shown above were derived after the factor analyses were run to reduce the variables to the six VFI functions. In parentheses, we have also included the Likert means to assist with interpretation. 
Table 4

MANOVA Findings: Race as the Grouping Variable

Multivariate Tests

\begin{tabular}{ccccccc} 
& & & & & \multicolumn{2}{c}{ Observed } \\
\hline Race & Wilks' $\lambda$ & $F$ & $d f$ & Sig. & Partial $\eta^{2}$ & Power \\
\hline
\end{tabular}

Tests of Between-Subjects Effects

\begin{tabular}{|c|c|c|c|c|c|c|c|c|}
\hline & $\begin{array}{c}\text { VFI } \\
\text { Function }\end{array}$ & $\begin{array}{c}\text { Type III Sum } \\
\text { of Squares }\end{array}$ & $d f$ & Mean Square & $F$ & Sig. & Partial $\eta^{2}$ & $\begin{array}{c}\text { Observed } \\
\text { Power }\end{array}$ \\
\hline \multirow[t]{6}{*}{ Race } & Protective function & 4.134 & 1 & 4.134 & 4.115 & $.045 * *$ & .031 & .521 \\
\hline & Values function & 1.143 & 1 & 1.143 & .917 & .340 & .007 & .158 \\
\hline & Career function & 3.873 & 1 & 3.873 & 3.269 & $.073 *$ & .025 & .434 \\
\hline & Social function & 3.143 & 1 & 3.143 & 2.780 & $.098 *$ & .021 & .380 \\
\hline & Understanding function & 2.390 & 1 & 2.390 & 2.050 & .155 & .016 & .295 \\
\hline & Enhancement function & 2.739 & 1 & 2.739 & 2.502 & .116 & .019 & .348 \\
\hline \multirow[t]{6}{*}{ Error } & Protective function & 128.576 & 128 & 1.005 & & & & \\
\hline & Values function & 159.600 & 128 & 1.247 & & & & \\
\hline & Career function & 151.682 & 128 & 1.185 & & & & \\
\hline & Social function & 144.735 & 128 & 1.131 & & & & \\
\hline & Understanding function & 149.204 & 128 & 1.166 & & & & \\
\hline & Enhancement function & 140.149 & 128 & 1.095 & & & & \\
\hline \multirow[t]{6}{*}{ Total } & Protective function & 132.710 & 129 & & & & & \\
\hline & Values function & 160.743 & 129 & & & & & \\
\hline & Career function & 155.556 & 129 & & & & & \\
\hline & Social function & 147.878 & 129 & & & & & \\
\hline & Understanding function & 151.594 & 129 & & & & & \\
\hline & Enhancement function & 142.888 & 129 & & & & & \\
\hline
\end{tabular}

Note: $* p<0.10, * * p<0.05, * * * p<0.01$

en a service-learning course. This was true for the complete MANOVA model as well as the individual univariate models for each outcome variable considered separately. Therefore, all student responses were combined for subsequent analyses.

Our final sample included 130 usable student responses. The descriptive statistics for the grouping variables and the VFI functions (after the factor analyses were conducted) are shown in Table 3 . We note that, for the descriptive statistics of the VFI functions, it is inappropriate to interpret negative values as necessarily implying negative impacts; rather, these values are useful for comparing between groups. Consistently throughout the findings, females reported greater levels than men on each of the VFI functions, and minority students reported greater levels than White students on each of the VFI functions. Whether or not these differences are statistically significant are indicated and described below and in Tables 4, 5, 6, and 7 .

In Table 4, we present the findings from the first of the four MANOVA models, which examines race as the single grouping variable. The results of the multivariate tests were not statistically significant, $F(6,123)=0.863, p=0.524$. When examined individually through the tests of between-subjects effects, race did have statistically significant effect on three of the VFI functions: protective, career, and social.

Table 5 shows the findings of the second MANOVA model, which examines gender as the single grouping variable. The results of the multivariate tests in this model were statistically significant, $F(6,123)=2.105, p=0.057$. When examined individually through the between-subjects effects, gender had a statistically significant effect on five of the six VFI functions, social being the lone exception.

In Table 6, we present the findings of the third MANOVA model, in which we examined both race and gender as grouping variables. In the multivariate tests, race again is not statistically significant, $F(6,122)=0.945, p=0.466$, and gender remains statistically significant, $F(6,122)=2.182, p=0.049$. When examined individually through the betweensubjects effects, race has a statistically significant effect on four of the six VFI functions (protective, career, social, and enhancement), and gender again has a statistically significant effect on five of the six VFI functions, with social again being the lone exception.

The findings of the fourth and final MANOVA 
Table 5

MANOVA Findings: Gender and the Grouping Variable

Multivariate Tests

\begin{tabular}{ccccccc}
\hline & & & \multicolumn{3}{c}{ Observed } \\
& Wilks' $\lambda$ & $F$ & $d f$ & Sig. & \multicolumn{3}{c}{ Partial $\eta^{2}$} & Power \\
\hline Gender & .907 & 2.105 & $(6,123)$ & $.057 *$ & .093 & .738 \\
\hline
\end{tabular}

Tests of Between-Subjects Effects

\begin{tabular}{|c|c|c|c|c|c|c|c|c|}
\hline & VFI Function & $\begin{array}{c}\text { Type III Sum } \\
\text { of Squares }\end{array}$ & $d f$ & $\begin{array}{l}\text { Mean } \\
\text { Square }\end{array}$ & $F$ & Sig. & Partial $\eta^{2}$ & $\begin{array}{c}\text { Observed } \\
\text { Power }\end{array}$ \\
\hline \multirow[t]{6}{*}{ Gender } & Protective function & 4.204 & 1 & 4.204 & 4.188 & $.043 * *$ & .032 & .528 \\
\hline & Values function & 9.217 & 1 & 9.217 & 7.786 & $.006 * * *$ & .057 & .791 \\
\hline & Career function & 11.467 & 1 & 11.467 & 10.187 & $.002 * * *$ & .074 & .886 \\
\hline & Social function & 2.382 & 1 & 2.382 & 2.096 & .150 & .016 & .301 \\
\hline & Understanding function & 9.974 & 1 & 9.974 & 9.015 & $.003 * * *$ & .066 & .846 \\
\hline & Enhancement function & 7.402 & 1 & 7.402 & 6.993 & $.009 * * *$ & .052 & .747 \\
\hline \multirow[t]{6}{*}{ Error } & Protective function & 128.506 & 128 & 1.004 & & & & \\
\hline & Values function & 151.526 & 128 & 1.184 & & & & \\
\hline & Career function & 144.089 & 128 & 1.126 & & & & \\
\hline & Social function & 145.496 & 128 & 1.137 & & & & \\
\hline & Understanding function & 141.620 & 128 & 1.106 & & & & \\
\hline & Enhancement function & 135.486 & 128 & 1.058 & & & & \\
\hline \multirow[t]{6}{*}{ Total } & Protective function & 132.710 & 129 & & & & & \\
\hline & Values function & 160.743 & 129 & & & & & \\
\hline & Career function & 155.556 & 129 & & & & & \\
\hline & Social function & 147.878 & 129 & & & & & \\
\hline & Understanding function & 151.594 & 129 & & & & & \\
\hline & Enhancement function & 142.888 & 129 & & & & & \\
\hline
\end{tabular}

Note: $* p<0.10, * * p<0.05, * * * p<0.01$

model are presented in Table 7. In this model, we examined race and gender as grouping variables as well as the interaction of those terms. In the multivariate tests, race was not statistically significant, $F(6,121)=0.567, p=0.756$, and the interaction of race and gender was also not statistically significant, $F(6,121)=1.337, p=0.246$. As in the second and third models, gender was again statistically significant, $F(6,121)=2.512, p=0.025$. When examined individually through the between-subjects effects, race no longer had a statistically significant effect on any of the six VFI functions; gender continued to have a statistically significant effect on five the six VFI functions (with social again being the lone exception); and interaction term had a statistically significant effect on the values, career, and understanding functions.

To summarize, when considering the ANOVA models and findings from the multivariate tests, only gender had a statistically significant effect on the outcome variables in the three models in which it was included as a grouping variable. It is important to note that the effect sizes (partial $\eta^{2}$ ) for gender are fairly small in the second, third and fourth models $(0.093,0.097$, and 0.111 , respectively).

Although gender was the only grouping variable with a statistically significant effect in the multivariate tests, it is also worth summarizing the results of the between-subjects effects for the individual VFI functions. For the protective function, race is statistically significant in the first model, in which race is the single grouping variable, and remains statistically significant in the third model, which examines both race and gender as grouping variables. However, in the final model, which adds the interaction term, race is no longer statistically significant. In all three models in which it was examined as a grouping variable, gender was statistically significant. In the final model, the interaction term is not statistically significant.

For the values function, race does not have a statistically significant effect in any of the three models in which it is included; however, gender does have a statistically significant effect for all three models in which it is included. Finally, the interaction term between race and gender also has a statistically significant effect in the final model.

For the career function, race has a statistically significant effect in the model in which it is the sole grouping variables and remains statistically significant when gender is also examined. However, when the interaction term is included in the final model, 
Table 6

MANOVA Findings: Race and Gender as Grouping Variables

Multivariate Tests

\begin{tabular}{lllllll} 
& & \multicolumn{2}{c}{ Wilks' $\lambda$} & & \multicolumn{2}{c}{ Observed } \\
\hline Race & .956 & & $d f$ & Sig. & Partial $\eta^{2}$ Power \\
Gender & .903 & .945 & $(6,122)$ & .466 & .044 & .362 \\
\hline
\end{tabular}

Tests of Between-Subjects Effects

\begin{tabular}{|c|c|c|c|c|c|c|c|c|}
\hline & VFI Function & $\begin{array}{c}\text { Type III Sum } \\
\text { of Squares }\end{array}$ & $d f$ & Mean Square & $F$ & Sig. & Partial $\eta^{2}$ & $\begin{array}{c}\text { Observed } \\
\text { Power }\end{array}$ \\
\hline \multirow[t]{6}{*}{ Race } & Protective function & 4.265 & 1 & 4.265 & 4.360 & $.039 * *$ & .033 & .545 \\
\hline & Values function & 1.246 & 1 & 1.246 & 1.053 & .307 & .008 & .175 \\
\hline & Career function & 4.083 & 1 & 4.083 & 3.704 & $.057 *$ & .028 & .480 \\
\hline & Social function & 3.229 & 1 & 3.229 & 2.883 & $.092 *$ & .022 & .392 \\
\hline & Understanding function & 2.544 & 1 & 2.544 & 2.323 & .130 & .018 & .328 \\
\hline & Enhancement function & 2.881 & 1 & 2.881 & 2.759 & $.099 *$ & .021 & .378 \\
\hline \multirow[t]{6}{*}{ Gender } & Protective function & 4.335 & 1 & 4.335 & 4.431 & $.037 * *$ & .034 & .551 \\
\hline & Values function & 9.320 & 1 & 9.320 & 7.876 & $.006 * * *$ & .058 & .795 \\
\hline & Career function & 11.677 & 1 & 11.677 & 10.592 & $.001 * * *$ & .077 & .898 \\
\hline & Social function & 2.468 & 1 & 2.468 & 2.203 & .140 & .017 & .314 \\
\hline & Understanding function & 10.128 & 1 & 10.128 & 9.249 & $.003 * * *$ & .068 & .855 \\
\hline & Enhancement function & 7.544 & 1 & 7.544 & 7.225 & $.008 * * *$ & .054 & .760 \\
\hline \multirow[t]{6}{*}{ Error } & Protective function & 124.241 & 127 & .978 & & & & \\
\hline & Values function & 150.280 & 127 & 1.183 & & & & \\
\hline & Career function & 140.005 & 127 & 1.102 & & & & \\
\hline & Social function & 142.267 & 127 & 1.120 & & & & \\
\hline & Understanding function & 139.076 & 127 & 1.095 & & & & \\
\hline & Enhancement function & 132.605 & 127 & 1.044 & & & & \\
\hline \multirow[t]{6}{*}{ Total } & Protective function & 132.710 & 129 & & & & & \\
\hline & Values function & 160.743 & 129 & & & & & \\
\hline & Career function & 155.556 & 129 & & & & & \\
\hline & Social function & 147.878 & 129 & & & & & \\
\hline & Understanding function & 151.594 & 129 & & & & & \\
\hline & Enhancement function & 142.888 & 129 & & & & & \\
\hline
\end{tabular}

Note: $* p<0.10, * * p<0.05, * * * p<0.01$

race is no longer statistically significant. Gender as a grouping variable has a statistically significant in all three models in which it is examined. Finally, the interaction term has a statistically significant effect on the career function.

For the social function, race is statistically significant when it is examined as the single grouping variable and remains statistically significant when gender is added in the third model. However, in the final model in which the interaction term is added as a grouping variable, race is no longer statistically significant. Gender does not have a statistically significant effect in any of the models, and the interaction term also does not have a statistically significant effect on the social function.

For the understanding function, race as a grouping variable does not have a statistically significant effect in any of the models in which it is included. Gender, on the other hand, is statistically significant in all three of the models in which it is includ- ed. Finally, the interaction term is also statistically significant in the final model when it is included.

Finally, for the enhancement function, race is statistically significant only in the third model, when race and gender are both examined as grouping variables; it is not statistically significant in first or final models. Gender as a grouping variable is statistically significant in all three models in which it is included, and the interaction term is not statistically significant when it is added in the final model.

Overall, when race is examined alone as a grouping variable, it has a statistically significant effect on the protective, career, and social functions; the enhancement function is also statistically significant in the third model. In the final model, race is not statistically significant for any of the VFI functions. Gender, on the other hand, has a statistically significant effect for five of the VFI functions (the social function being the exception) in all three models in which it is included. Finally, the interac- 
Table 7

MANOVA Findings: Race, Gender, and their Interaction as Grouping Variables

Multivariate Tests

\begin{tabular}{lcccccc} 
& Wilks' $\lambda$ & $F$ & $d f$ & Sig. & Partial $\eta^{2}$ & $\begin{array}{c}\text { Observed } \\
\text { Power }\end{array}$ \\
\hline Race & .973 & .567 & $(6,121)$ & .756 & .027 & .220 \\
Gender & .889 & 2.512 & $(6,121)$ & $.025^{* *}$ & .111 & .823 \\
Race * & .938 & 1.337 & $(6,121)$ & .246 & .062 & .507 \\
Gender & & & & & & \\
\hline
\end{tabular}

Tests of Between-Subjects Effects

\begin{tabular}{|c|c|c|c|c|c|c|c|c|}
\hline & VFI Function & $\begin{array}{l}\text { Type III Sum } \\
\text { of Squares }\end{array}$ & $d f$ & $\begin{array}{l}\text { Mean } \\
\text { Square }\end{array}$ & $F$ & Sig. & Partial $\eta^{2}$ & $\begin{array}{c}\text { Observed } \\
\text { Power }\end{array}$ \\
\hline \multirow[t]{6}{*}{ Race } & Protective function & 1.566 & 1 & 1.566 & 1.594 & .209 & .012 & .240 \\
\hline & Values function & .362 & 1 & .362 & .316 & .575 & .003 & .086 \\
\hline & Career function & .110 & 1 & .110 & .103 & .749 & .001 & .062 \\
\hline & Social function & 1.738 & 1 & 1.738 & 1.540 & .217 & .012 & .234 \\
\hline & Understanding function & .016 & 1 & .016 & .015 & .903 & .000 & .052 \\
\hline & Enhancement function & 660 & 1 & .660 & .631 & .428 & .005 & .124 \\
\hline \multirow[t]{6}{*}{ Gender } & Protective function & 4.545 & 1 & 4.545 & 4.626 & $.033 * *$ & .035 & .569 \\
\hline & Values function & 10.588 & 1 & 10.588 & 9.264 & $.003 * * *$ & .068 & .856 \\
\hline & Career function & 12.869 & 1 & 12.869 & 11.980 & $.001 * * *$ & .087 & .930 \\
\hline & Social function & 2.505 & 1 & 2.505 & 2.219 & .139 & .017 & .315 \\
\hline & Understanding function & 11.357 & 1 & 11.357 & 10.715 & $.001 * * *$ & .078 & .901 \\
\hline & Enhancement function & 7.921 & 1 & 7.921 & 7.575 & $.007 * * *$ & .057 & .780 \\
\hline \multirow{6}{*}{$\begin{array}{l}\text { Race * } \\
\text { Gender }\end{array}$} & Protective function & .458 & 1 & .458 & .466 & .496 & .004 & .104 \\
\hline & Values function & 6.268 & 1 & 6.268 & 5.484 & $.021 * *$ & .042 & .642 \\
\hline & Career function & 4.648 & 1 & 4.648 & 4.327 & $.040 * *$ & .033 & .542 \\
\hline & Social function & .042 & 1 & .042 & .037 & .848 & .000 & .054 \\
\hline & Understanding function & 5.526 & 1 & 5.526 & 5.213 & $.024 * *$ & .040 & .620 \\
\hline & Enhancement function & .843 & 1 & .843 & .806 & .371 & .006 & .145 \\
\hline \multirow[t]{6}{*}{ Error } & Protective function & 123.783 & 126 & .982 & & & & \\
\hline & Values function & 144.012 & 126 & 1.143 & & & & \\
\hline & Career function & 135.357 & 126 & 1.074 & & & & \\
\hline & Social function & 142.225 & 126 & 1.129 & & & & \\
\hline & Understanding function & 133.550 & 126 & 1.060 & & & & \\
\hline & Enhancement function & 131.763 & 126 & 1.046 & & & & \\
\hline \multirow[t]{6}{*}{ Total } & Protective function & 132.710 & 129 & & & & & \\
\hline & Values function & 160.743 & 129 & & & & & \\
\hline & Career function & 155.556 & 129 & & & & & \\
\hline & Social function & 147.878 & 129 & & & & & \\
\hline & Understanding function & 151.594 & 129 & & & & & \\
\hline & Enhancement function & 142.888 & 129 & & & & & \\
\hline
\end{tabular}

Note: $* p<0.10, * * p<0.05, * * * p<0.01$

tion of gender and race has a statistically significant effect in the final model (the only model in which it is included) for three of the VFI functions: values, career, and understanding.

\section{Discussion}

While acknowledging the exploratory nature of this study and its inherent generalizability limitations, we believe that the findings emphasize our primary contention - students are motivated to participate in service-learning for a variety of reasons based on their backgrounds and experiences. In general, it appears that a student's race can affect her or his individual motivational functions related to service-learning courses, and when there is a significant difference, minority students report greater levels of motivation than White students. The minority students motivated by enhancement function may be expecting service-learning to empower them with feelings of self-efficacy that come from the responsibility and autonomy that often are associated with service-learning courses.

Related to students' egos, minority students also may be more motivated by the protective function because they feel guilt for being more fortunate 
than others from their racial group, or may be using service-learning to protect themselves from feelings of isolation or other stresses. Assuaging feelings of isolation may also contribute to students motivated by the social function, as well as the perceived expectation that they should give back to their communities. Finally, minority students may be motivated by the career function because they feel that service-learning can provide them with the skills necessary to secure employment in their chosen fields. These findings align with the student responses reported in Pearl and Christensen (2016) that indicate minority students may lack intrinsic advantages (such as high levels of social capital) and subsequently enroll in service-learning courses to make up for these potential deficits.

However, a student's race does not appear to be nearly as impactful as the student's gender, even to the degree that when gender is examined in the MANOVA models in conjunction with race the statistically significant effect of race diminishes or disappears completely. With the exception of the social function, women report greater levels of motivations for five of the six VFI functions. Regarding the values function, female students may be motivated to participate in service-learning because it provides them with an outlet to develop and express their attitudes and values related to social responsibility (Clary et al., 1998; Stukas et al., 1999). Similar to minority students, female students appear to see service-learning as an opportunity to both enhance and protect their egos, allowing them to be more engaged in their courses and in their college experience in general, which can lead to increased feelings of responsibility and self-efficacy. This, in turn, may account for female students' motivations related to the career and understanding functions, such that they gain valuable and marketable skills in addition to the confidence to utilize those skills - important qualities due to the fact that women face many of the same intrinsic disadvantages as minority students.

Finally, it is important to note that while the multivariate effects were not statistically significant for the interaction term in the last model, the values, career, and understanding functions were all statistically significant when examined individually. While exploratory in nature, these findings are indicative of the inherent complexity of students' identities, consistent with Jones and McEwen's (2000) model of multiple dimensions of identity (see also, Abes, Jones, \& McEwen, 2007; Jones, 2009). As students navigate their multiple forms of identity, such as race and gender, and balance those identities within the contextual influences within which they operate, they are in a continually shifting state of their different identities playing a role in their actions at any given time. Especially at a time when students are learning more about themselves, they are working to sort out how to balance their dominant and non-dominant identities. They ways in which these identities intersect has been shown to influence student motivation for community service involvement (Jones \& Hill, 2003).

So what do these findings tell us? First, it may indicate that both minority and female students are differently motivated than their White and male counterparts, which may, in part, help explain some of the results of previous work indicating differing outcomes for students based on their backgrounds (Chesler \& Vasques Scalera, 2000; Coles, 1999; Green, 2001; Mitchell \& Donahue, 2009). Our findings build on these previous studies by providing a more nuanced understanding of what motivates students to achieve positive learning, personal, and social outcomes.

The findings from the current study support other scholarship (Pearl \& Christensen, 2016) that suggest that students from different backgrounds may have different motivations for enrolling in servicelearning courses. Students may seek to satisfy different needs and have different expectations in terms of anticipated outcomes. As service-learning instructors and administers, we can point to myriad examples of how participating in a service-learning experience can positively affect students, and as a field, we have spent a great amount of time and energy to better understand these student outcomes (as well as the outcomes for communities, faculty members, and institutions). However, we have paid less attention to inputs such as student traits and motivations. Previous research has suggested that how instructors frame reflection strategies can influence students' outcomes (Einfeld \& Collins, 2008). If instructors have a clearer idea of what motivates different types of students, they can frame recruitment and reflection activities to better help students achieve their goals.

Further, it is important for service-learning instructors to consider their own identities and perspectives when framing these reflection strategies and resist the temptation or natural proclivity to frame reflections based on their own identities and lenses. Instructors need to be purposeful in ensuring that reflection strategies and the prompts they provide speak to all students and their identities. For example, minority students may be uncomfortable when engaging in conversations about race with their White classmates (Seider, Huguley, \& Novick, 2013). Further, because a large number of service-learning projects are involved with minori- 
ty communities, what message does this send to students from these minority communities?

Given the differences that emerged in the findings between the motivations of male and female students, it is also important to consider how service-learning is viewed (and rewarded) structurally by the institutions. If service and teaching have traditionally been viewed as "women's work" (Park, 1996), we may be sending a problematic message to students that service-learning is less rigorous and prestigious. We believe our findings support existing calls to further explore viewing community engagement through a feminist lens (Iverson \& James, 2014).

As with any empirical study, there are certain limitations to our work. For example, our work is based on a relatively small sub-set of students from one (albeit large, public) institution. It would be imprudent to generalize these findings to all students. Further, we acknowledge that our consideration of the race of students as either White or minority is an oversimplification of race and how students identify with this complex trait. We also acknowledge the limitations of self-reported data and possibilities of mono-method bias.

Despite these issues, we believe that this exploratory work sets the foundation for continued research with more robust samples of students. The results of this study raise several questions that can be addressed through continued inquiry. For example, how do students' motivations and other inputs affect their learning outcomes? And, how do individual students' personal narratives influence their motivation for engaged learning? The current study only examines the student inputs for servicelearning. Ultimately, we believe that building a comprehensive dataset inclusive of students' motivations, detailed experiences in service-learning courses, and a wide range of learning outcomes will continue to help us understand how participating in service-learning affects students.

Future research should also include in-depth qualitative analysis. When examined in concert with the findings of Pearl and Christensen (2016), the current study suggests that there may be motivational differences among students but only hypothesizes as to why these differences exist. In particular, we believe one methodological approach that may be highly instructive is narrative inquiry (Connelly \& Clandinin, 1990). This approach allows for in-depth exploration of students' identities, how they developed those identities, and provides a more nuanced approach to the racial and ethnic perspectives of individuals rather than the simplistic categorization of White or minority. Further, this would open the door for the exploration of individual identities not included in this study.

From the perspective of research and advancing our knowledge of service-learning in higher education, this study establishes a foundation that better accounts for students" "inputs" in order to better understand various service-learning outcomes. We also propose that administrators and servicelearning instructors consider our findings from the perspective of how service-learning courses are delivered. Research has suggested that instructors are able to emphasize student outcomes based on the reflection prompts they give to students (Einfeld \& Collins, 2008). Therefore, if students are motivated to achieve different outcomes and enroll in service-learning for different purposes, it is useful for instructors to understand these motivations when constructing their course syllabi and reflection strategies.

Finally, to close the gap between minority student interest and actual enrollment in servicelearning courses, administrators should strategize how to communicate the ways that enrolling in service-learning can help students satisfy their motivations and achieve their higher education goals. Clary et al. (1998) stress the importance of persuasive messaging when it comes to appealing to individuals' motivations to volunteer; a similar approach should be taken to match the messaging of service-learning's potential positive impacts to the various motivations of students. This is particularly important given that Clary et al. also found that when the motivations of volunteers and the situational fits of their service roles are aligned, they are likely to continue to serve in the future. This lesson should be considered for students enrolled in service-learning courses.

If we are not purposeful in how we speak to the various motivations of our students, and some of those students do not have positive experiences with service-learning, are we essentially telling some of them that their active participation in society through service is not important? If a goal of service-learning is to develop future engaged citizen-leaders, we must make sure that we provide engaging service-learning experiences with all of our students in mind. Therefore, it is important to continue to unpack students' complex motives for participating in service-learning.

\section{References}

Abes, E. S., Jones, S. R., \& McEwen, M. K. (2007). Reconceptualizing the model of multiple dimensions of identity: The role of meaning-making capacity in the construction of multiple identities. Journal of College Student Development, 48(1), 1-22. 
Allison, L. D., Okun, M. A., \& Dutridge, K. S. (2002). Assessing volunteer motives: A comparison of an openended probe and Likert rating scales. Journal of Community \& Applied Social Psychology, 12(4), 243-255.

Astin, A. W. (2012). Assessment for excellence: The philosophy and practice of assessment and evaluation in higher education. Lanham, MD: Rowman \& Littlefield Publishers.

Battistoni, R.M. (2012). Civic learning through service learning. In P. H. Clayton, R. G. Bringle, \& J. A. Hatcher (Eds.), Research on service-learning: Conceptual frameworks and assessment: Volume 2A: Students and faculty (pp. 111-132). Sterling, VA: Stylus.

Brandenberger, J.W. (2012). Investigating personal development outcomes in service learning. In P. H. Clayton, R. G. Bringle, \& J. A. Hatcher (Eds.), Research on service-learning: Conceptual frameworks and assessment: Volume 2A: Students and faculty (pp. 133-156). Sterling, VA: Stylus.

Brayley, N., Obst, P., White, K. M., Lewis, I. M., Warburton, J., \& Spencer, N. M. (2014). Exploring the validity and predictive power of an extended volunteer functions inventory within the context of episodic skilled volunteering by retirees. Journal of Community Psychology, 42(1), 1-18.

Bringle, R. G., Phillips, M. A., \& Hudson, M. (2004). The measure of service learning: Research scales to assess student experiences. Washington, DC: American Psychological Association.

Brown, E., \& Lankford, H. (1992). Gifts of money and gifts of time: Estimating the effects of tax prices and available time. Journal of Public Economics, 47(3), 321-341.

Bryant, W. K., Jeon-Slaughter, H., Kang, H., \& Tax, A. (2003). Participation in philanthropic activities: Donating money and time. Journal of Consumer Policy, 26(1), 42-73.

Butin, D. W. (2006). The limits of service-learning in higher education. The Review of Higher Education, 29(4), 473-498. doi:10.1353/rhe.2006.0025

Chesler, M., \& Scalera, C. V. (2000). Race and gender issues related to service-learning research. Michigan Journal of Community Service Learning, Special Issue, 18-27.

Christensen, R. K., Stritch, J. M., Kellough, J. E., \& Brewer, G. A. (2015). Identifying student traits and motives to service-learn: Public service orientation among new college freshmen. Journal of Higher Education Outreach and Engagement, 19(4), 39-62. Retrieved from http://openjournals.libs.uga.edu/index. $\mathrm{php} / \mathrm{jheoe} / \mathrm{article} / \mathrm{view} / 1530$

Clary, E. G., Snyder, M., Ridge, R. D., Copeland, J., Stukas, A. A., Haugen, J. et al. (1998). Understanding and assessing the motivations of volunteers: A functional approach. Journal of Personality and Social Psychology, 74(6), 1516-1530. Retrieved from http://www.ncbi. nlm.nih.gov/pubmed/9654757

Clayton, P. H., Bringle, R. G., \& Hatcher, J. A. (Eds.). (2012). Research on service-learning: Conceptual frameworks and assessment: Volume 2A: Students and faculty. Sterling, VA: Stylus.
Coles, R. (1999). Race-focused service-learning courses: Issues and recommendations. Michigan Journal of Community Service Learning, 6, 97-105.

Connelly, F. M., \& Clandinin, D. J. (1990). Stories of experience and narrative inquiry. Educational Researcher, 19(5), 2-14.

Deardorff, D.K, \& Edwards, K.E. (2012). Framing and assessing students' intercultural competence in service learning. In P. H. Clayton, R. G. Bringle, \& J. A. Hatcher (Eds.), Research on service-learning: Conceptual frameworks and assessment: Volume 2A: Students and faculty (pp. 157-183). Sterling, VA: Stylus.

Einfeld, A., \& Collins, D. (2008). The relationships between service-learning, social justice, multicultural competence, and civic engagement. Journal of College Student Development, 49(2), 95-109. Retrieved from http://search.proquest.com/docview/195183025?accountid $=159965$

Einolf, C. (2011). Gender differences in the correlates of volunteering and charitable giving. Nonprofit and Voluntary Sector Quarterly, 40(6), 1092-1112. doi:10.1177/ 0899764010385949

Eyler, J., Giles, D., \& Gray, C. (1999). At a glance: What we know about the effects of service-learning on students, faculty, institutions, and communities, 1993 1999. Nashville, TN: Vanderbilt University.

Finkelstein, M. A. (2008). Volunteer satisfaction and volunteer action: A functional approach. Social Behavior and Personality: An International Journal, 36(1), 918.

Fitch, P., Steinke, P., \& Hudson, T.D. (2012). Research and theoretical perspectives on cognitive outcomes of service learning. In P. H. Clayton, R. G. Bringle, \& J. A. Hatcher (Eds.), Research on service-learning: Conceptual frameworks and assessment: Volume 2A: Students and faculty (pp. 57-84). Sterling, VA: Stylus.

Fletcher, T. D., \& Major, D. A. (2004). Medical students' motivations to volunteer: An examination of the nature of gender differences. Sex Roles, 51(1-2), 109-114.

Green, A. E. (2001). "But you aren't White": Racial perceptions and service-learning. Michigan Journal of Community Service Learning, 8(1), 18-26.

Hogg, M. A., \& Terry, D. I. (2000). Social identity and self-categorization processes in organizational contexts. Academy of Management Review, 25(1), 121140.

Huberty, C. J. \& Petoskey, M. D. (2000). Multivariate analysis of variance and covariance. In H. E. Tinsley \& S. D. Brown (Eds.), Handbook of applied multivariate statistics and mathematical modeling. San Diego, CA: Academic Press.

Iverson, S. V. \& James, J. H. (2014). Feminism and community engagement: An overview. In S. V. Iverson \& J. H. James (Eds.), Feminist community engagement: Achieving praxis (pp. 9-27). New York: Palgrave MacMillan.

Jacoby, B. (2015). Service-learning essentials: Questions, answers, and lessons learned. San Francisco: Jossey-Bass.

Jameson, J.K., Clayton, P.H., \& Ash S.L. (2012). Con- 
ceptualizing, assessing, and investigating academic learning in service learning. In P. H. Clayton, R. G. Bringle, \& J. A. Hatcher (Eds.), Research on servicelearning: Conceptual frameworks and assessment: Volume 2A: Students and faculty (pp. 85-110). Sterling, VA: Stylus.

Jones, S. R. (2009). Constructing identities at the intersections: An autoethnographic exploration of multiple dimensions of identity. Journal of College Student Development, 50(3), 287-304.

Jones, S. R., \& Hill, K. E. (2003). Understanding patterns of commitment: Student motivation for community service involvement. The Journal of Higher Education, 74(5), 516-539.

Jones, S. R., \& McEwen, M. K. (2000). A conceptual model of multiple dimensions of identity. Journal of College Student Development, 41(4), 405-414.

Katz, D. (1960). The functional approach to the study of attitudes. Public Opinion Quarterly, 24(2), 163-204.

Lai, M. H., Ren, M. Y., Wu, A., \& Hung, E. P. (2013). Motivation as mediator between national identity and intention to volunteer. Journal of Community \& Applied Social Psychology, 23(2), 128-142.

Laurence, J. (2009). The effect of ethnic diversity and community disadvantage on social cohesion: A multilevel analysis of social capital and interethnic relations in UK communities. European Sociological Review. Advance online publication. doi:10.1093/esr/jcp057

Matthews, P., Pearl, A., \& Wilder, S., (2014, October). Characteristics of effective practice by faculty in service-learning courses. Poster presented at the Annual Conference of the Engagement Scholarship Consortium, Edmonton, AB, Canada.

Manud, P. (2014). Understanding what motivates participation in environmental digital citizen science across different sectors of society in the United Kingdom. Unpublished master's thesis, Imperial College, London, England. Retrieved from http://www.iccs.org.uk/ wp-content/uploads/2011/10/Maund_Phoebe_ConSci_2014.pdf

Mesch, D. J., Rooney, P. M., Steinberg, K. S., \& Denton, B. (2006). The effects of race, gender, and marital status on giving and volunteering in Indiana. Nonprofit and Voluntary Sector Quarterly, 35(4), 565-587.

Mitchell, T. D., \& Donahue, D. M. (2009). "I do more service in this class than I ever do at my site": Paying attention to the reflections of students of color in service-learning. In J. Strait \& M. Lima (Eds.), The future of service-learning: New solutions for sustaining and improving practice (pp. 172-190). Sterling, VA: Stylus Publishing.

Moely, B. E., \& Ilustre, V. (2014). The impact of servicelearning course characteristics on university students' learning outcomes. Michigan Journal of Community Service Learning, 21(1), 5-17.

Musick, M., \& Wilson, J. (2008). Volunteers: A social profile. Bloomington, IN: Indiana University Press

Musick, M. A., Wilson, J., \& Bynum, W. E. (2000). Race and formal volunteering: The differential effects of call and religion. Social Forces, 78(4), 1539-1571.
Okun, M. A., Barr, A., \& Herzog, A. (1998). Motivation to volunteer by older adults: A test of competing measurement models. Psychology and Aging, 13(4), 608621.

Okun, M. A., \& Schultz, A. (2003). Age and motives for volunteering: Testing hypotheses derived from socioemotional selectivity theory. Psychology and Aging, 18(2), 231-239.

Olney, C., \& Grande, S. (1995). Validation of a scale to measure development of social responsibility. Michigan Journal of Community Service Learning, 2, 43-53.

Park, S. M. (1996). Research, teaching, and service: Why shouldn't women's work count? The Journal of Higher Education, 67(1), 46-84.

Pearl A. \& Christensen, R. K. (2016, October). First-year student motivations for service-learning: Exploring minority student perceptions. Paper presented at the Annual Conference of the Engagement Scholarship Consortium, Omaha, NE.

Rotolo, T., \& Wilson, J. (2011). State-level differences in volunteering in the United States. Nonprofit and Voluntary Sector Quarterly. Advance online publication. doi: $10.1177 / 0899764011412383$

Schatteman, A. M. (2014). Academics meets action: Community engagement motivations, benefits, and constraints. Journal of Community Engagement and Higher Education, 6(1), 17-30.

Seider, S., Huguley, J. P., \& Novick, S. (2013). College students, diversity, and community service learning. Teachers College Record, 115(3), 1-44.

Smith, M. T. (2002, November). The decision to volunteer: Do childhood human capital investments impact the valuation of time? Paper presented at the ARNOVA Annual Conference, Montreal, Canada.

Smith, M., Bruner, J., \& White, R. (1956). Opinions and personality. New York: Wiley.

Stukas, A.A., Clary, E.G., \& Snyder, M. (1999). Servicelearning: Who benefits and why. Social Policy Report: Society for Research in Child Development, 13(4), 119.

Tavakol, M., \& Dennick, R. (2011). Making sense of Cronbach's alpha. International Journal of Medical Education, 2, 53-55.

Terrell, F., Moseley, K. L., Mosley, K. L., Terrell, A. S., \& Nickerson, K. J. (2004). The relationship between motivation to volunteer, gender, cultural mistrust, and willingness to donate organs among Blacks. Journal of the National Medical Association, 96(1), 53-60.

Van Slyke, D. M., Ashley, S., \& Johnson, J. L. (2007). Nonprofit performance, fund-raising effectiveness, and strategies for engaging African Americans in philanthropy. The American Review of Public Administration, 37(3), 278-305.

Van Slyke, D. M., \& Eschholz, S. (2002, November). Are women more generous than men? Gender differences in motivations for charitable giving. Paper presented at the ARNOVA Annual Conference, Montreal, Canada.

Wilson, J. \& Musick, M. (1997). Who cares? Toward an integrated theory of volunteer work. American Sociological Review, 65(5), 694-713. 
Authors

ANDREW J. PEARL (andrew.pearl@ung.edu) serves as the University of North Georgia's first director of academic engagement, where his responsibilities include faculty development, building mutually-beneficial community-university partnerships, and fostering an institutional culture supportive of community engagement. His scholarship focuses on faculty member motivations related to the scholarship of engagement, student motivations and outcomes related to service-learning experiences, and institutional and public policies that affect community engagement in higher education. He received his Ph.D. from the University of Georgia's Institute of Higher Education.
ROBERT K. CHRISTENSEN (rkc@byu.edu) is an associate professor in Brigham Young University's Romney Institute of Public Management. He received his Ph.D. from Indiana University. His research interests include public service career attraction and socialization in higher education. $\mathrm{He}$ is a research fellow at Arizona State University's Center for Organization Research \& Design and a co-researcher at Seoul National University's Center for Government Competitiveness. He is a faculty advisor at Brigham Young University's Grantwell, a student-run, faculty-advised philanthropic consulting and service-learning program. 
Appendix A

\begin{tabular}{|c|c|c|c|c|c|}
\hline \multirow[t]{2}{*}{ Function } & \multirow[t]{2}{*}{ Item } & \multicolumn{2}{|c|}{$\begin{array}{l}\text { Current or previous } \\
\text { SL experience }\end{array}$} & \multicolumn{2}{|c|}{$\begin{array}{l}\text { No prior SL } \\
\text { experience }\end{array}$} \\
\hline & & Mean & Std. Dev. & Mean & Std. Dev. \\
\hline \multirow[t]{5}{*}{$\begin{array}{l}\text { Protective } \\
\text { function }\end{array}$} & $\begin{array}{l}\text { No matter how bad I've been feeling, my (a) ser- } \\
\text { vice-learning course can (would) help me to forget } \\
\text { about it }\end{array}$ & 3.51 & 1.089 & 3.13 & .995 \\
\hline & $\begin{array}{l}\text { My (a) service-learning course (would) make(s) me feel } \\
\text { less lonely }\end{array}$ & 3.17 & 1.069 & 3.14 & 1.023 \\
\hline & $\begin{array}{l}\text { Participating in service-learning (would) relieve(s) me } \\
\text { of some of the guilt over being more fortunate than } \\
\text { others }\end{array}$ & 3.08 & 1.193 & 3.16 & 1.106 \\
\hline & $\begin{array}{l}\text { My experience with service-learning (would) help(s) me } \\
\text { work through my own personal problems }\end{array}$ & 3.24 & 1.208 & 3.36 & 1.009 \\
\hline & $\begin{array}{l}\text { My (a) service-learning course can (would) provide me } \\
\text { with a good escape from my own troubles }\end{array}$ & 3.24 & 1.088 & 3.38 & 1.048 \\
\hline \multirow{5}{*}{ Values function } & I am concerned about those less fortunate than myself & 4.19 & .999 & 4.34 & .777 \\
\hline & $\begin{array}{l}\text { When I serve, I am genuinely concerned about the par- } \\
\text { ticular group I am serving }\end{array}$ & 4.05 & .990 & 4.09 & .878 \\
\hline & I feel compassion toward people in need & 4.29 & .911 & 4.43 & .734 \\
\hline & I feel it is important to help others & 4.41 & .873 & 4.61 & .623 \\
\hline & I can do something for a cause that is important to me & 3.98 & 1.080 & 4.24 & .730 \\
\hline \multirow[t]{5}{*}{ Career function } & $\begin{array}{l}\text { Service-learning can (would) help me to get my foot in } \\
\text { the door in a field where I would like to work }\end{array}$ & 3.97 & .999 & 3.65 & 1.067 \\
\hline & $\begin{array}{l}\text { I can make new contacts that might help my future } \\
\text { career }\end{array}$ & 3.78 & 1.035 & 4.11 & .838 \\
\hline & $\begin{array}{l}\text { Service-learning (would) allow(s) me to explore differ- } \\
\text { ent career options }\end{array}$ & 3.79 & .913 & 3.81 & .948 \\
\hline & $\begin{array}{l}\text { My experience in service-learning will (would) help me } \\
\text { to succeed in my chosen profession }\end{array}$ & 3.70 & 1.025 & 3.69 & .905 \\
\hline & $\begin{array}{l}\text { A service-learning course will (would) look good on my } \\
\text { resume }\end{array}$ & 4.05 & .818 & 4.22 & .818 \\
\hline \multirow[t]{5}{*}{ Social function } & $\begin{array}{l}\text { I have friends who are enrolled in service-learning } \\
\text { courses }\end{array}$ & 3.56 & 1.134 & 2.74 & 1.108 \\
\hline & $\begin{array}{l}\text { People I'm close to want me to enroll in a service-learn- } \\
\text { ing course }\end{array}$ & 3.02 & 1.068 & 2.79 & 1.050 \\
\hline & $\begin{array}{l}\text { People I know share an interest in taking a ser- } \\
\text { vice-learning course }\end{array}$ & 3.58 & .962 & 3.32 & 1.011 \\
\hline & $\begin{array}{l}\text { Others with whom I am close place a high value on } \\
\text { service-learning }\end{array}$ & 3.55 & .902 & 3.31 & 1.049 \\
\hline & $\begin{array}{l}\text { Service-learning is an important activity to the people I } \\
\text { know best }\end{array}$ & 3.55 & .952 & 3.22 & 1.068 \\
\hline \multirow[t]{5}{*}{$\begin{array}{l}\text { Understanding } \\
\text { function }\end{array}$} & $\begin{array}{l}\text { I can (would) learn more about the cause or communi- } \\
\text { ty with which I am working in my service-learning } \\
\text { course }\end{array}$ & 4.25 & .863 & 4.22 & .705 \\
\hline & $\begin{array}{l}\text { Service-learning (would) allow(s) me to gain a new } \\
\text { perspective on things }\end{array}$ & 4.10 & .969 & 4.25 & .785 \\
\hline & $\begin{array}{l}\text { Service-learning (would) let(s) me learn things through } \\
\text { direct, hands-on experience }\end{array}$ & 4.10 & .959 & 4.24 & .810 \\
\hline & I can learn how to deal with a variety of people & 4.14 & .773 & 4.26 & .697 \\
\hline & I can explore my own strengths & 4.07 & .871 & 4.13 & .804 \\
\hline \multirow[t]{5}{*}{$\begin{array}{l}\text { Enhancement } \\
\text { function }\end{array}$} & $\begin{array}{l}\text { Providing community service through my service-learn- } \\
\text { ing course (would) make(s) me feel important }\end{array}$ & 3.91 & .923 & 4.02 & .873 \\
\hline & Service-learning (would) increase(s) my self-esteem & 3.71 & .911 & 3.60 & .915 \\
\hline & Service-learning (would) make(s) me feel needed & 3.61 & 1.021 & 3.64 & .931 \\
\hline & $\begin{array}{l}\text { Service-learning (would) make(s) me feel better about } \\
\text { myself }\end{array}$ & 3.48 & 1.062 & 3.74 & .905 \\
\hline & $\begin{array}{l}\text { A service-learning course is (would be) a way to make } \\
\text { new friends }\end{array}$ & 4.00 & .853 & 4.15 & .712 \\
\hline
\end{tabular}

